\title{
Exploring management approaches for water and energy in the data-scarce Tekeze-Atbara Basin under hydrologic uncertainty
}

DOI:

10.1080/07900627.2019.1591941

\section{Document Version}

Accepted author manuscript

Link to publication record in Manchester Research Explorer

Citation for published version (APA):

Basheer, M., Sulieman, R., \& Ribbe, L. (2019). Exploring management approaches for water and energy in the data-scarce Tekeze-Atbara Basin under hydrologic uncertainty. International Journal of Water Resources Development, 1-26. https://doi.org/10.1080/07900627.2019.1591941

Published in:

International Journal of Water Resources Development

\section{Citing this paper}

Please note that where the full-text provided on Manchester Research Explorer is the Author Accepted Manuscript or Proof version this may differ from the final Published version. If citing, it is advised that you check and use the publisher's definitive version.

\section{General rights}

Copyright and moral rights for the publications made accessible in the Research Explorer are retained by the authors and/or other copyright owners and it is a condition of accessing publications that users recognise and abide by the legal requirements associated with these rights.

\section{Takedown policy}

If you believe that this document breaches copyright please refer to the University of Manchester's Takedown Procedures [http://man.ac.uk/04Y6Bo] or contact uml.scholarlycommunications@manchester.ac.uk providing relevant details, so we can investigate your claim.

\section{OPEN ACCESS}




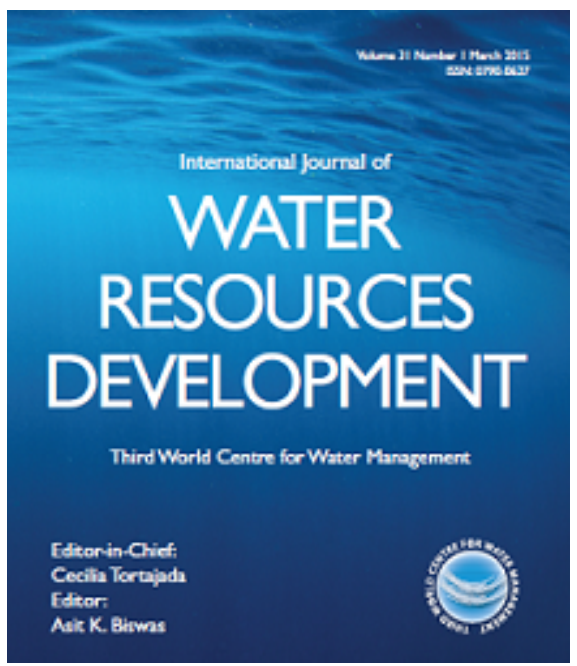

\section{Exploring management approaches for water and energy in the data-scarce Tekeze-Atbara Basin under hydrologic uncertainty}

\begin{tabular}{|r|l|}
\hline Journal: & International Journal of Water Resources Development \\
\hline Manuscript ID & CIJW-2018-0349.R3 \\
\hline Manuscript Type: & Original Paper \\
\hline Keywords: & $\begin{array}{l}\text { Nile Basin, storage dams, satellite-based rainfall products, satellite- } \\
\text { based reservoir monitoring, water-energy nexus, coordination }\end{array}$ \\
\hline \multicolumn{2}{|l}{} \\
\end{tabular}

\section{SCHOLARONE \\ Manuscripts}




\section{Exploring management approaches for water and energy in the data-}

2 scarce Tekeze-Atbara Basin under hydrologic uncertainty

3 Mohammed Basheer ${ }^{\mathrm{a}, \mathrm{b}}$ *, Rayyan Suliemana, c, Lars Ribbe ${ }^{\mathrm{a}, \mathrm{d}}$

$4 \quad{ }^{a}$ Institute for Technology and Resources Management in the Tropics and Sub-tropics

5 (ITT), Technische Hochschule Köln, Betzdorferstr. 2, 50679, Cologne, Germany

$6 \quad{ }^{b}$ Current affiliation: School of Mechanical, Aerospace, and Civil Engineering, The

7 University of Manchester, Manchester, United Kingdom

8

9 *Corresponding author's email: mohammedadamabbaker@gmail.com

10 c email: rayyotop@gmail.com

11 d email: lars.ribbe@th-koeln.de 


\section{Exploring management approaches for water and energy in the data- 14 scarce Tekeze-Atbara Basin under hydrologic uncertainty}

This study examines management approaches for hydropower generation and irrigation and domestic water supply for Tekeze-Atbara, a transboundary river between Ethiopia, Eritrea, and Sudan, under above- and below- normal hydrologic conditions considering current and future water demand scenarios. Satellite data are used to substitute unavailable or inaccessible ground meteorological and dam data. Based on three examined coordination scenarios, the analysis finds that coordinating the management of the Sudanese dams would bring significant benefits to water supply and energy generation. An optimisation analysis is necessary to reveal the full value of coordination of dams in TekezeAtbara Basin.

Keywords: Nile Basin; storage dams; satellite-based rainfall products; satellitebased reservoir monitoring; water-energy nexus; coordination

\section{Introduction}

Access to sustainable water, energy, and food sources has become a major concern in the modern-day especially under the ongoing rapid changes in the natural and human environments. The demands for water, energy, and food in the Eastern Nile Basin (ENB) countries (Figure 1) are speedily growing due to population growth, economic development, and urbanisation (NBI, 2012). From 1990 to 2017, the total population of the ENB countries increased from around 134 to 260 million (UN, 2017) and the Human Development Index of the individual countries grew at different rates except for South Sudan (UNDP, 2018). Moreover, around 80 million of the population of the ENB countries lived in urban areas in 2017 compared to approximately 38 million in 1990 with the expectation to reach about 217 million by 2050 (UN, 2018). On the other hand, climate change is expected to exhibit large-scale changes in the elements of the hydrologic cycle such as precipitation and runoff (IPCC, 2008; N. Stern, 2006). For 
40 East Africa, several studies projected an increase in precipitation (Shongwe, Van

41 Oldenborgh, Van Den Hurk, \& Van Aalst, 2011), whereas others reported a decrease

42 (Souverijns, Thiery, Demuzere, \& Lipzig, 2016). Moreover, river flow has been

projected to increase in large parts of East Africa coupled with more frequent

successions of floods and a decrease in the severity of droughts (Cole, Elliott, \& Strobl,

2014; Shongwe et al., 2011). In light of the above pressures and challenges, fulfilling

the present and future water, energy, and food demands requires consistent plans and targets for water management (García-Vera, 2013), efficient and optimally-operated

energy generation systems (Boadi \& Owusu, 2017; Peng, Xu, \& Liu, 2016), and

enhanced agricultural practices (Amekawa, 2009; Møller, Drews, \& Larsen, 2017;

Pradhan, Sijapati, \& Bajracharya, 2015). Further, understanding the interdependences of

water, energy, and food systems is imperative for their sustainable management (Al-

Saidi \& Elagib, 2017; Liu et al., 2017). Several studies investigated the nexus of water,

energy, and food in a variety of contexts and spatial and temporal scales and concluded

the importance of their joint management (Bazilian et al., 2011; Chirisa \& Bandauko,

2015; Engström et al., 2017; Kurian, 2017; Larsen \& Drews, 2019; Lindström \& Granit, 2012).

Tekeze-Atbara River, the last major tributary of the Nile River before it ends in the Mediterranean Sea, is geographically shared between Ethiopia, Eritrea, and Sudan (Sutcliffe \& Parks, 1999). Numerous studies have been published for the Nile Basin on

60 the management of water and energy resources under a variety of scenarios and climatic

61 conditions. However, few focused on or tested water management strategies for Tekeze-

62 Atbara Basin. A recent study by Digna, Mohamed, van der Zaag, Uhlenbrook, \& Corzo

63 (2017) reviewed 36 published and unpublished simulation and optimisation models that

64 have been developed between 1958 and 2016 on management and planning of the Nile 
water resources (e.g. Arjoon, Mohamed, Goor, \& Tilmant, 2014; Block \& Strzepek, 2010; Goor, Halleux, Mohamed, \& Tilmant, 2010; Guariso, Haynes, Whittington, \& Younis, 1981; Guariso \& Whittington, 1987; Jeuland, 2010; King \& Block, 2014; Lee, Yoon, \& Shah, 2012; Levy \& Baecher, 1999; McCartney \& Menker Girma, 2012; Satti, Zaitchik, \& Siddiqui, 2015; Stedinger, Sule, \& Loucks, 1984; Wheeler et al., 2016; Whittington, Waterbury, \& Jeuland, 2014; Whittington, Wu, \& Sadoff, 2005; Y. Zhang, Block, Hammond, \& King, 2015). The study revealed that 10 of the 36 reviewed Nile models included Tekeze-Atbara in their modelling domains. Nevertheless, only one of the ten models, i.e. Abreha (2010), examined scenarios to quantify trade-offs between energy generation and water supply for Tekeze-Atbara Basin. A number of other studies have been recently published on modelling the water resources of the Nile Basin of which three were limited to the Blue Nile Basin (Basheer et al., 2018; Mekonnen, Duan, Rientjes, \& Disse, 2018; Stamou \& Rutschmann, 2018), one to the White Nile Basin (Basheer \& Elagib, 2018b), one to Tekeze-Atbara Basin (Abera, Asfaw, Engida, \& Melesse, 2018), three to the ENB (Digna et al., 2018; Mulat, Moges, \& Moges, 2018; Wheeler et al., 2018), and one covered the whole Nile Basin (Jeuland, Wu, \& Whittington, 2017). Apart from Abera et al. (2018), none of the recent studies focused on testing management scenarios for Tekeze-Atbara Basin. Abera et al. (2018) developed a monthly model for Tekeze-5 Dam (see Figure 1) to optimise its operation for hydropower production under Representative Concentration Pathway (RCP) 4.5 and 8.5 climate scenarios. They found that climate change would increase hydropower production from the dam by 25 to $30 \%$. Previous studies that focused on Tekeze-Atbara Basin, as reviewed above, helped to improve the understandings on the management of water and energy in the Basin. Nevertheless, they relied on monthly models and consequently simplified some elements of the river system that vary from day to day 
90 and inherently influence water supply and hydropower generation (e.g. dam outlet

91 capacities, dam operating rules, tailwater elevation) (World Bank, 1980). Moreover, they used deterministic hydrologic conditions to drive their model simulations. three coordination scenarios for cascade dams in Tekeze-Atbara Basin for hydropower generation and irrigation and domestic water supply. Tekeze-Atbara River was selected herein because there is still little scientific understanding of it, as reviewed above,

97 although it contributes roughly $15 \%$ of the annual flow of the Nile as measured at Aswan near the Sudanese-Egyptian border. Moreover, it suffers from metrological and hydrologic data-scarcity, which enables presenting alternative sources and innovative

100 methods to obtain data. In this study, a daily river basin model is developed, calibrated, 101 and validated for Tekeze-Atbara for the period 1984-2016 to include river flow, irrigation water demands, domestic water demands, and hydropower storage dams. The model simulates rainfall-runoff of sub-basins with limited/unavailable data, water

104 allocation to hydropower and water supply, and irrigation water demands of future

105 schemes. Due to the few operating rainfall stations in the study area, point-to-pixel 106 evaluation is conducted for five long-term Satellite-based Rainfall Products (SRPs), and

107 the best performing one is used as a boundary condition to the rainfall-runoff

108 component of the model. Satellite imagery is used to derive the past reservoir water

109 levels of Tekeze-5 Dam because no data about them were accessible for this study. The

110 present analysis examines 36 scenarios which result from the combinations of three dam

111 coordination levels (business as usual, coordination within Sudan, and sub-basin

112 coordination), two water demand scenarios (current and future), and six starting water

113 levels for Tekeze-5 Dam. Each of the scenarios is examined across 50 above-normal

114 and 50 below-normal stochastic hydrologic sequences that are developed by 
115 bootstrapping from the historic flow record. The present analysis is not meant to

116 quantify the costs and benefits of coordination in Tekeze-Atbara Basin, as the examined

117 scenarios do not include the full expected future water demands, nor is an optimisation

118 model used to modify the operation of the river system. However, the examined

119 scenarios are hoped to inform the decision makers of the Tekeze-Atbara Basin and other

120 basins on the importance of coordinated management of river systems especially under

121 sustained above- or below-normal hydrologic conditions which are anticipated to occur

122 before the middle of the 21 st century (Hirabayashi, Kanae, Emori, Oki, \& Kimoto,

123 2008; IPCC, 2008). The remaining part of this paper is composed of four main sections:

124 the first gives an overview of Tekeze-Atabra Basin and its water-related infrastructures;

125 the second deals with the methodology used for this study; the thrid analyses and

126 discusses the results; the fourth draws conclusions based on the other three sections.

\section{Study area}

\section{General features}

129 The study area encompasses Tekeze-Atbara Basin. Figure 1 shows the extent and

130 general characteristics of the study area. Tekeze-Atbara Basin is located in north-eastern

131 Africa and is geographically shared between Ethiopia, Eritrea, and Sudan. The basin

132 covers an area of around $231,000 \mathrm{~km}^{2}$ of which approximately $51 \%$ is in Sudan, $39 \%$ is

133 in Ethiopia, and 10\% is in Eritrea. Tekeze-Atbara River starts in north-western Ethiopia

134 at an altitude of above 4,500 $\mathrm{m}$ asl, where it is known as Tekeze River, and flows

135 northwest through the rugged topography of Ethiopia while small tributaries join the

136 mainstem from Ethiopia and Eritrea. The river enters Sudan at around $580 \mathrm{~m}$ asl where

137 it is called Setit River. Around $70 \mathrm{~km}$ downstream the Ethiopian-Sudanese border,

138 Upper Atbara, a main tributary that originates in Ethiopia, joins Setit River to form 
139 Atbara River. After that, Atbara continues northwest through the relatively flat terrain

140 of Sudan, gets joint by small streams, and merges with the Main Nile in Atbara Town at

141 around $350 \mathrm{~m}$ asl. The Main Nile continues northwards through North Sudan and Egypt

142 and ends in the Mediterranean Sea.

[Figure 1 near here]

144 The average annual flow of Tekeze-Atbara River is around 12,800 Mm3, which

145 accounts for approximately $15 \%$ of the average yearly flow of the Nile measured at

146 Aswan near the Sudanese-Egyptian border. On average, the current annual water

147 abstraction and reservoir evaporation in Tekeze-Atbara Basin account for around 1,900

148 and $800 \mathrm{Mm} 3$, respectively. High inter- and intra-annual variability characterises the

149 flow of Tekeze-Atbara (Zaghloul, El-Moattassem, \& Rady, 2007) with around 92\% of

150 the annual flow occurring from July to October (see Figure 2). Based on Köppen Geiger

151 climate classification, the study area comprises temperate (Cwb), tropical (Aw), and

152 arid (BSh and BWh) climates (H.E Beck et al., 2018).

[Figure 2 near here]

\section{Dams and hydropower}

155 Figures 1 and 3 show the locations of the three currently operating dams in the study

156 area and Table 1 reports their main attributes. The construction of Khashm Elgirba Dam

157 in Sudan, the oldest dam on Tekeze-Atbara River, was completed in 1964 to provide

158 irrigation water to New Halfa Scheme through headworks located on the left side of the

159 dam (World Bank, 1980). Both the dam and the irrigation scheme were built to resettle

16050,000 Sudanese that have been displaced as a result of the construction of the Egyptian

161 High Aswan Dam which has a reservoir that extends around $150 \mathrm{~km}$ inside Sudan

162 (Salman, 2016). According to the Ministry of Water Resources, Irrigation, and 
163 Electricity of Sudan, around $50 \%$ of the original storage capacity of Khashm Elgirba

164 has been lost due to sedimentation from 1964 to 1985 whereas roughly $6 \%$ has been lost

165 from 1986 to 2009. Khashm Elgirba Dam also serves in hydropower generation in two

166 ways (Institute of Hydrology, 1978; Sudanese Hydro Generation Co Ltd, 2011): (1)

167 downstream releases can be passed through two 5.3-MW Kaplan turbines; (2) water

168 diversion to New Halfa Scheme and Town can be passed through three 2.4-MW pump-

169 turbines when the reservoir water level is at least two meters higher than the water level

170 in the diversion canal. The three pump-turbines are also used to pump water from the

171 reservoir to the diversion canal when the reservoir water level drops below the canal

172 water level (Institute of Hydrology, 1978).

[Table 1 near here]

In 2009, Ethiopia completed the construction of Tekeze-5 Dam, the second

175 tallest double curvature concrete arch dam in Africa, to generate hydropower through

176 four 75-MW Frances turbines (Abera et al., 2018; Adera, 2015; Tekeze Inauguration

177 Bulletin, 2009; Welde, 2016). In 2015, the construction of Upper Atbara and Setit Dam

178 Complex (UASDC) was completed at a location right upstream the confluence of Upper

179 Atbara and Setit Rivers (see Figure 1). The latter River is called Tekeze in Ethiopia as

180 explained in the previous section. UASDC crosses both Upper Atbara and Setit Rivers

181 to form a common reservoir (Sloff, Omer, Heynert, \& Mohamed, 2015). The dam was

182 built to generate hydropower through four 80 -MW turbines, to provide irrigation water

183 to a future irrigation scheme called Upper Atbara, and to supply Gedarif Town with

184 domestic water through a pipeline that is currently under construction (Zoellner, Scheid,

185 \& Mukthar, 2017). The dam body includes two sets of outlets: (1) a powerhouse and a

186 spillway that release water to Upper Atbara River and (2) a spillway that discharges into

187 Setit River. Lastly several dams are planned for construction on the Ethiopian side of 
188 Tekeze-Atbara River (Digna et al., 2018). However, they were not included in this 189 study.

[Figure 3 near here]

\section{$191 \quad$ Irrigation and domestic water users}

192 Figures 1 and 3 illustrate existing water abstractions on Tekeze-Atbara in addition to 193 planned abstractions in the basin part of Sudan. The information available to us on

194 future irrigation and domestic water users in the Ethiopian and Eritrean parts of the

195 basin were not enough to estimate their water demands and therefore were not

196 considered. New Halfa, located in Sudan, is the only existing large-scale irrigation

197 scheme that withdraws water from Tekeze-Atbara River. The scheme has an area of

198 around 185,000 ha and was constructed during the 1960s to resettle the Sudanese

199 population that has been displaced due to the construction of the High Aswan Dam as

200 explained in the previous section. The scheme is located downstream Khashm Elgirba

201 Dam on the west bank of the river. A diversion canal is used to supply New Halfa

202 Scheme and Town with irrigation and domestic water, respectively, from Khashm

203 Elgirba Reservoir. Furthermore, Upper Atbara Irrigation Scheme is planned to be

204 constructed downstream Khashm Elgirba Dam on the east bank of the river. According 205 to the Ministry of Water Resources, Irrigation, and Electricity of Sudan, the scheme is

206 expected to have an area of around 300,000 ha and will likely be supplied with

207 irrigation water through headworks on the right side of Khashm Elgirba Dam. Lastly, a

208 pipeline is currently under construction to provide 450,000 residents of Gedarif Town

209 with domestic water from the reservoir of UASDC (Zoellner et al., 2017). 
210 Methodology

\section{Model description}

212 To examine management approaches for hydropower generation and irrigation and

213 domestic water supply, a daily river basin model was developed, calibrated, and

214 validated for Tekeze-Atbara for the period 1984 to 2016 to include hydropower dams,

215 large-scale irrigation schemes, significant domestic water users, and major inflows and

216 water losses. Figure 3 shows a schematic of the model developed for this study. The

217 model simulates rainfall-runoff of sub-basins with limited/unavailable data (i.e., sub-

218 basins 1 to 7), water allocation to hydropower and water supply, and irrigation water

219 demands of future schemes. The baseline model includes five main elements: three

220 dams (i.e., Tekeze-5 Dam, UASDC, and Khashm Elgirba Dam) and two water

221 consumers (i.e., New Halfa Irrigation Scheme and Town). Furthermore, the baseline

222 model includes eight inflow nodes (sub-basins 1 to 7 and Upper Atbara), evaporation

223 losses from storage reservoirs, and transmission losses from river reaches. Upper Atbara

224 Irrigation Scheme and Gedarif Town were included in future scenarios as explained in a

225 following section. The data used in developing and driving the model and their sources

226 are outlined in the following section.

227 Several methods were employed in modelling rainfall-runoff of sub-basins 1 to 7

228 including simple canopy interception, average monthly evapotranspiration, soil deficit

229 and constant loss calculations for infiltration, and Snyder unit hydrograph (HEC, 2000).

230 It is worth mentioning that all the parameters of the seven sub-basins were spatially

231 lumped. FAO Penman-Monteith equation (G. Allen, Pereira, Raes, \& Smith, 1998) was

232 used to estimate the irrigation water demands of the planned Upper Atbara Scheme. It

233 was assumed that Upper Atbara Scheme has a soil type similar to New Halfa Scheme

234 (i.e., clayey soil; The World Bank, (1980)) due to their proximity. Figure S2 in the 
235 online supplementary data shows the estimated irrigation water demands of Upper

236 Atbara Scheme. Fixed lag times and loss percentages were used to model channel travel

237 time and losses, respectively. Furthermore, average monthly evaporation coefficients

238 were applied to estimate evaporation losses from the storage reservoirs. The calibration

239 and validation criteria of the model are presented in a following section.

240 In this study, several modelling tools were utilised to simulate the different

241 processes. The Hydrologic Engineering Center-Hydrologic Modelling System (HEC-

242 HMS; HEC (2000)), CropWat (FAO, 2015), and RiverWare (Zagona, Fulp, Shane,

243 Magee, \& Morgan, 2001) were used to model rainfall-runoff, irrigation water demands,

244 and water allocation to hydropower generation and water users, respectively. Figure S3

245 in the online supplemental data displays the linkages between the three modelling tools

246 used in this study.

\section{Data used}

248 Daily data of river water levels at Kubor Station were obtained from the Ministry of

249 Water Resources, Irrigation, and Electricity of Sudan (MoWRIE) for the period 1984 to

250 2007. The water levels were used together with the concurrent rating curves to create a

251 river flow time series for the station. MoWRIE also provided river flow data for

252 Bardana and Rumela stations for the period 2008 to 2016, river flow data for Hamadiet

253 Station for 2013 to 2016, and reservoir water levels for UASDC for 2015 and 2016

254 (note that UASDC became operational in 2015). The inflow of Upper Atbara River for

2551984 to 2014 was compiled from Kubor Station (1984-2007) and Rumela Station (2008

256 to 2014). Moreover, the observed flow at Hamadiet Station (2015-2016), the observed

257 outflow from, and water levels of, UASDC (2015-2016), and evaporation losses from

258 UASDC were used to estimate the inflow of Upper Atbara River for 2015 and 2016

259 using water balance. For Khashm Elgirba Dam and UASDC, the geometry and monthly 
260 evaporation coefficients of the reservoirs, the outlet capacities, the specifications of the

261 hydropower turbines, the downstream discharge-water level relationships, and the

262 operating rules were obtained from MoWRIE. Apart from the operating rules, similar

263 data were attained for Tekeze-5 Dam from Wheeler et al. (2016) and the Eastern Nile

264 Technical Regional Office (ENTRO) of the Nile Basin Initiative (NBI). The method

265 used to derive the past reservoir water levels of Tekeze-5 Dam, explained in a following

266 section, utilises Landsat satellite images of the United States Geological Survey

267 (USGS). Furthermore, MoWRIE provided intermittent outflow data for Khashm Elgirba

268 Dam from 1984 to 2014, current water demands of New Halfa Scheme and Town,

269 future water demands of Gedarif Town, and the design cropping pattern and irrigation

270 efficiency of Upper Atbara Scheme. Due to poor coverage of Tekeze-Atbara Basin with

271 rainfall stations, five daily SRPs that cover the model period were evaluated, and the

272 best-performing one was used as a boundary condition to model the inflow from sub-

273 basins 1 to 7 (Figure 3). The evaluated SRPs are: Africa Rainfall Climatology Version

2742.0 (ARC2; Novella \& Thiaw (2013)), Climate Hazards group Infrared Precipitation

275 with Stations version 2.0 (CHIRPS V2.0; Funk et al. (2014)), Multi-Source Weighted-

276 Ensemble Precipitation version 2.0 (MSWEP 2.0; Hylke E Beck, Dijk, Levizzani,

277 Schellekens, \& Miralles (2017)), Precipitation Estimation from Remotely Sensed

278 Information Using Artificial Neural Networks-Climate Data Record (PERSIANN-

279 CDR; Ashouri et al. (2015)), and Tropical Applications of Meteorology Using Satellite

280 Data and Ground-Based Observations version 2.0 (TAMSAT-2; Tarnavsky et al.

281 (2014)). Daily rainfall data from seven ground stations for the period 1984 to 2007 were

282 used to evaluate the performance of the SRPs (Figure 1 shows the stations). The ground

283 rainfall data were obtained from the Sudan Meteorological Authority and ENTRO.

284 More information about the evaluation method of the SRPs is provided in the next 
285 section of this paper. The seven sub-basins (see Figure 3) were delineated based on the

286 90-m resolution topographic data of the Shuttle Radar Topography Mission (SRTM;

287 Jarvis, Reuter, Nelson, \& Guevara (2008)). The global monthly evapotranspiration data

288 of the Moderate Resolution Imaging Spectroradiometer Global Evapotranspiration

289 Project (MOD16; Mu, Zhao, \& Running (2011)), which covers the period 2000 to 2014,

290 were used to estimate the average monthly evapotranspiration from the seven sub-

291 basins. The climatic parameters required to estimate the irrigation water demands of

292 Upper Atbara Scheme were acquired from New_LocClim (FAO, 2014; Grieser,

293 Gommes, \& Bernardi (2006)), a database developed by the Food and Agriculture

294 Organization of the United Nations.

295 Key data utilised in this study are provided in the online supplementary file

296 (namely water abstractions, dam operating rules, and reservoir geometry and

297 evaporation coefficients).

\section{Evaluation of Satellite-based Rainfall Products}

299 Point-to-pixel evaluation was conducted to assess the daily performance of the five

300 selected SRPs (i.e., ARC2, CHIRPS V2.0, MSWEP 2.0, PERSIANN-CDR, and

301 TAMSAT-2) through the period 1984 to 2007. This method compares satellite-

302 estimated rainfall at locations of ground rainfall stations with the concurrent rainfall

303 records of the stations. This method is suitable for regions with sparse rainfall stations

304 (Basheer \& Elagib, 2018a), and therefore was selected for this study. R programming

305 language (R Core Team, 2015) was used to download the SRPs and to carry out the

306 evaluation. To measure the disparity between the satellite estimates and the ground

307 observations, three metrics were used: the Root Mean Square Error (RMSE; Equation

308 1), the Mean Bias Error (MBE; Equation 2), and the coefficient of determination $\left(\mathrm{R}^{2}\right.$;

309 Equation 3). Whereas RMSE shows the magnitude of the average error and can take any 
310 value from zero (indicates no error) to $+\infty$ (signals a high error), MBE describes the

311 direction of error bias and varies between $-\infty$ and $+\infty$ (both indicate a high error), with

312 no error at zero. $\mathrm{R}^{2}$ measures how well the estimated values correlate with the observed

313 values and varies from zero (total disagreement) to one (perfect correlation). To assess

314 the detection skills of the SRPs, four categorical metrics were selected, which are based

315 on dichotomous evaluation of each time step within the assessment period (rainy/non-

316 rainy). The selected categorical metrics are the Probability Of Detection (POD), the

317 False Alarm Ratio (FAR), and the Equitable Threat Score (ETS). In order to calculate

318 the three selected categorical metrics, a threshold of $0.1 \mathrm{~mm} /$ day was used to classify

319 each time step within the evaluation period into the following: a hit, $h$, when rainfall

320 was both observed at the station and estimated by the Satellite-based Rainfall Product

321 (SRP); a miss, $\mathrm{m}$, when rainfall was observed at the station but not estimated by the

322 SRP; a false alarm, f, when rainfall was estimated by the SRP but not observed at the

323 station; or a null, $\mathrm{n}$, when rainfall was neither observed at the station nor estimated by

324 the SRP. Equations 4, 5, and 6 were used to calculate POD, FAR, and ETS,

325 respectively. POD gives the fraction of observations that were successfully detected and

326 ranges from zero, indicating no observation was detected, to one, indicating all

327 observations were detected. On the other hand, FAR measures the fraction of

328 estimations that were not observed. It ranges from zero, which indicates that all

329 estimations were observed, to one, which indicates that all estimations were not

330 observed. Lastly, ETS gives the portion of observations and estimations that were

331 correctly detected, adjusted for the number of hits (He; Equation 7) that would be

332 expected by random chance. It varies from $-1 / 3$, which is the worst value, to one, which

333 is the perfect value.

$$
R M S E=\sqrt{\frac{1}{n} \sum_{i=1}^{n}\left(E_{i}-O_{i}\right)^{2}}
$$




$$
\begin{gathered}
M B E=\frac{1}{n} \sum_{i=1}^{n}\left(E_{i}-O_{i}\right) \\
R^{2}=\frac{\left(n\left(\sum_{i=1}^{n} O_{i} E_{i}\right)-\left(\sum_{i=1}^{n} O_{i}\right)\left(\sum_{i=1}^{n} E_{i}\right)\right)^{2}}{\left(n\left(\sum_{i=1}^{n} O_{i}^{2}\right)-\left(\sum_{i=1}^{n} O_{i}\right)^{2}\right)\left(n\left(\sum_{i=1}^{n} E_{i}^{2}\right)-\left(\sum_{i=1}^{n} E_{i}\right)^{2}\right)} \\
P O D=\frac{H}{H+M} \\
F A R=\frac{F}{H+F} \\
E T S=\frac{H-H_{e}}{H+M+F-H_{e}} \\
H_{e}=\frac{(H+M)(H+F)}{N}
\end{gathered}
$$

341 Where $\mathrm{O}_{\mathrm{i}}$ is the $\mathrm{i}^{\text {th }}$ observed value, $\mathrm{E}_{\mathrm{i}}$ is the $\mathrm{i}^{\text {th }}$ estimated value, $\mathrm{n}$ is the number of data

342 pairs, $\mathrm{H}$ is the total number of hits, $\mathrm{M}$ is the total number of misses, $\mathrm{F}$ is the total

343 number of false alarms, and $\mathrm{N}$ is the total number of nulls.

344 Based on the above procedure, ARC2 was selected as the overall best performing SRP

345 in the study area and was used as an input to model rainfall-runoff of sub-basins 1 to 7.

346 The supplementary data to this article provides and discusses the results of the

347 performance evaluation of ARC2, CHIRPS V2.0, MSWEP 2.0, PERSIANN-CDR, and 348 TAMSAT-2.

\section{Satellite-based reservoir water level estimation}

350 For this study, no ground data were accessible on the filling approach or the steady

351 operation of Tekeze-5 Dam. Therefore, Landsat satellite images were used together with

352 the elevation-area table of Tekeze-5 Reservoir to derive a time series of the reservoir 353 water level from the filling commencement until the end of 2016. To achieve that, the 
354 following steps were taken:

355

356

357

358

359

360

361

362

363

364

365

366

367

368

369

370

371

372

373

374

375

376

377

- Landsat images were downloaded for the period from January 2007 to

December 2016. The images were filtered based on cloud cover, sun azimuth, and clarity over the area of Tekeze- 5 Reservoir. Accordingly, 71 images were selected for use through the period January 2007 to December 2016.

- For the 71 images, the reservoir water surface was classified, and the reservoir area was calculated.

- The elevation-area table of Tekeze-5 Reservoir was used to determine the water levels that correspond with the 71 area values which were derived in the previous step. To this end, the reservoir water level was known at 71 timesteps.

- Linear interpolation between the 71 values of reservoir water level was performed to create a daily water level time series for Tekeze-5 Reservoir.

Figure 4 shows the surface area of Tekeze-5 Reservoir once every year from the start of the filling until 2016. The figure also displays the time series of the reservoir water level that was derived based on the steps mentioned above. Figure 4 illustrates that Tekeze- 5 Reservoir was $54 \%$ full by the end of 2009 , a result that agrees with information reported by Tekeze Inauguration Bulletin (2009) that the filling was 52\% complete by the end of 2009. The evidence from Figure 4 shows that the filling of Tekeze-5 Reservoir started in August 2007 and the reservoir reached the Full Supply Level (FSL) in September 2011. In this study, the satellite-estimated water levels of Tekeze- 5 were used as a target to model the operation of the dam throughout the filling period (i.e., from August 2007 to September 2011). From October 2011 onwards, it was assumed that Tekeze-5 Dam is operated to target a fixed power level while maintaining the reservoir at a water level higher than the Minimum Operating Level (MOL) and 
378 lower than FSL. This assumption was because the primary purpose of the dam is energy

379 production. Several power targets were tested for the period October 2011 to December

3802016 , and one was selected based on the correspondence between the modelled and the

381 satellite-estimated water levels in that period. Accordingly, a 300-MW power target was

382 selected (see Figure S4 in the online supplemental data). Therefore, the following

383 operating policy was adopted for Tekeze-5 Dam: targeting a constant power rate of 300

384 MW while maintaining the reservoir water level between the MOL and the FSL.

[Figure 4 near here]

\section{Model calibration and validation}

387 The model was calibrated and validated at Khashm Elgirba Dam utilising intermittent

388 outflow data that were available for this study. Whereas the calibration period extends

389 from 1984 to 1999 , the validation period covers 2000 to 2016 . The physical parameters

390 of sub-basins 1 to 7 in addition to the travel times and loss percentages of river reaches

391 constitute the parameters used to calibrate the model. For basins 1 to 7 , the calibration

392 parameters are the initial and maximum storage of plant canopy, the initial and

393 maximum deficit of soil moisture, the constant infiltration rate of soil, the standard lag,

394 and the peaking coefficient (HEC, 2000). The model performance was assessed based

395 on quantitative comparison of the observed and simulated outflows from Khashm

396 Elgirba Dam using six statistical metrics: Nash-Sutcliffe coefficient of Efficiency (NSE;

397 Equation 8), R² (Equation 3), MBE (Equation 2), RMSE (Equation 1), POD (Equation

398 4), and FAR (Equation 5). NSE can take any value from one to $-\infty$ with one indicating

399 perfect prediction ability, zero indicating that the prediction of the model is as good as

400 the mean observed data, and negative values showing that the mean observed data is

401 better than the model prediction. 


$$
N S E=1-\frac{\sum_{i=1}^{n}\left(E_{i}-O_{i}\right)^{2}}{\sum_{i=1}^{n}\left(O_{i}-\overline{O_{i}}\right)^{2}}
$$

Where $\mathrm{O}_{\mathrm{i}}$ is the $\mathrm{i}^{\text {th }}$ observed value, $\mathrm{E}_{\mathrm{i}}$ is the $\mathrm{i}^{\text {th }}$ estimated value, $\mathrm{n}$ is the number

404 of data pairs, and $\overline{O_{i}}$ is the mean of observed values.

407 Figure 2.a). For this reason, the model performance was assessed in two different

408 periods in the year: July to October and November to June. Whereas NSE was used to

409 measure the perdition ability of the model in relation to the mean observed data, $\mathrm{R}^{2}$ was

410 used to show the fraction of variation in the observed data that could be explained by

411 the model. MBE and RMSE were used to indicate the magnitude and direction of error

412 in the model estimations; POD and FAR were used to assess the skill of the model in

413 detecting flow events. To calculate POD and FAR, a threshold of $0.5 \mathrm{Mm} 3 /$ day was

414 used to classify each calibration or validation time step into a hit, h, when flow was both

415 observed and estimated, a miss, $\mathrm{m}$, when flow was observed but not estimated, a false

416 alarm, f, when flow was estimated but not observed, or a null, $\mathrm{n}$, when flow was neither

417 observed nor estimated.

\section{$418 \quad$ Scenarios analysed}

419 This study aims to explore management approaches for water and energy in Tekeze-

420 Atbara Basin under prolonged above- and below-normal hydrologic conditions. For this

421 purpose, 36 scenarios were examined (see Figure S5 in the online supplemental data).

422 The scenarios result from the combinations of three dam coordination levels, two

423 demand scenarios, and six starting water levels of Tekeze-5 Dam. Each of the scenarios

424 was subject to 50 above-normal and 50 below-normal hydrologic sequences that have a 
425 20-year length. The combinations of the scenarios and the hydrologic sequences result 426 in a total of 3600 simulations.

427 Three dam coordination scenarios were examined in this study: business as 428 usual, coordination within Sudan, and sub-basin coordination. Tables S1 to S3 in the 429 online supplemental data report the operating rules of Khashm Elgirba Dam, UASDC, 430 and Tekeze-5 Dam in the three coordination scenarios. In the business as usual scenario, 431 it was assumed that the operation of the three dams would continue as of their current 432 operation. Currently, the primary purpose of Tekeze-5 Dam and UASDC is hydropower 433 generation whereas Khashm Elgirba Dam is operated for water supply and energy 434 generation. Moreover, measures are taken in the operation of UASDC and Khashm 435 Elgirba Dam to control reservoir sedimentation by flushing and seasonal fluctuation of 436 water levels (World Bank, 1980). In the scenario of coordination within Sudan, the 437 original operating rules of Tekeze-5 and Khashm Elgirba dams were sustained, and the 438 operation of UASDC was amended by allowing it to make extra water releases to meet 439 the downstream water supply deficits. In the sub-basin coordination scenario, Khashm 440 Elgirba Dam and UASDC were operated like in the case of coordination within Sudan 441 while Tekeze-5 Dam was set to make extra water releases to cover the downstream 442 water supply deficits when the other two dams are unable to satisfy the water demands.

443 The rationale behind the selection of the three scenarios is exploring three levels of 444 coordination: (1) unilateral operation of dams which may result in water supply 445 shortages, (2) in-country coordination to reduce water supply shortages, and (3) sub446 basin coordination to further lower water supply deficits. We acknowledge that the 447 selected dam operation scenarios are not optimal nor do they reflect the exact path to 448 coordination for Tekeze-Atbara Basin. However, the present analysis would shed light 449 on the potential benefits and costs of coordination within a highly understudied basin 
450 and would pave the way for further examinations. It is important to mention that the

451 operating rules of Tekeze-5 Dam, UASDC, and Khashm Elgirba Dam in the three

452 scenarios are based on the current operation of the three dams, thus do not vary across

453 dry and wet years. In this study, two demand scenarios were examined: a current

454 demand scenario with only New Halfa Scheme and Town included as water consumers;

455 a future demand scenario with New Halfa Irrigation Scheme and Town, Upper Atbara

456 Irrigation Scheme, and Gedarif Town incorporated in the system. Although Ethiopia has

457 agricultural development plans involving Tekeze-Atbara Basin, their data were

458 inaccessible for this study. Moreover, little information is published about them as

459 revealed by a review of the literature. In order to develop demand scenarios that include

460 the Ethiopian part of the basin, one needs to know the areas, locations, and cropping

461 patterns of planned irrigation schemes. While we acknowledge not considering the

462 future water demands of Ethiopia as a limitation, we believe that the analysed scenarios

463 would be an addition to the literature and a starting point for future studies. Because

464 Tekeze-5 is a multi-year storage dam, six scenarios for the initial water level of the dam

465 were examined: 1,096 m asl (i.e., MOL), 1,100 $\mathrm{m}$ asl, 1,110 $\mathrm{m}$ asl, 1,120 $\mathrm{m}$ asl, 1,130 m 466 asl, and 1,140 $\mathrm{m}$ asl (i.e., FSL).

467 In this study, 50 above-normal and 50 below-normal hydrologic sequences with 468 a 20-year length were stochastically generated based on the historic flow record. A 20469 year extent was chosen to exemplify prolonged above- or below-normal conditions. To 470 create the hydrologic sequences, the Standardized Streamflow Index (SSFI; Modarres 471 (2007)) was calculated for the total annual flow for 1984 to 2016 (Figure 2.b). Positive 472 and Negative SSFI values were used to classify the years into above- and below-normal 473 years, respectively. SSFI was selected due to the normality in the distribution of the 474 historic annual river flow data explained by a low skewness coefficient of 0.58 . After 
475 the years were classified, 50 above-normal (below-normal) hydrologic sequences with a 476 20-year length were created by repeating the following process 50 times: the bootstrap 477 method (Efron, 1992) was used to resample from the historic above-normal (below478 normal) years 20 times with replacement. This method was used due to its simplicity 479 and the absence of clear serial correlation or dependence in the historic above- or 480 below-normal years (Ebtehaj, Moradkhani, \& Gupta, 2010; Noguchi, Gel, \& Duguay, 481 2011). Figure S6 in the supplementary data shows the hydrologic sequences generated 482 in this study.

\section{Results and discussion}

\section{Model performance}

485 Figure 5 shows the observed and simulated outflow from Khashm Elgirba Dam in the calibration and validation periods. The evidence from Figure 5.a shows that the model corresponds well with the hydrologic cycle in both the calibration and validation periods. The scatter plots (Figures 5.b and 5.c) show a fair distribution of points around the one-to-one line confirmed by the slope values of the regression lines which are around 0.8 and 0.9 in the calibration and validation periods, respectively. This characteristic suggests no systematic error in the estimates of the model.

Table 2 reports the values of the performance metrics for the calibration and

494 validation periods. For July to October, the values of NSE and $\mathrm{R}^{2}$ indicate good to very

495 good performances in the calibration and validation periods based on the

496 recommendations of M. Stern, Flint, Minear, Flint, \& Wright (2016) for performance

497 ranking of models. The values of MBE for July to October reveal overall overestimation

498 by the model. The high RMSE values of July to October, compared to MBE, are due to 
499 the tendency of the metric to magnify the error amounts. This attribute of RMSE has

500 been highlighted by Elagib, Alvi, \& Mansell (1999) among several others. POD and

501 FAR values for July to October show that the model detected a high fraction of the

502 observed flow days and falsely estimated flow in a small number of days. This good

503 detection capability from July to October is because it is easier for the model to capture

504 flow events in the flood season than in the dry season. The values of MBE and RMSE

505 show less perdition error from November to June than from July to October. For

506 November to June, the model correctly detected more flow events in the validation

507 period than in the calibration as shown by POD, falsely identified fewer flow events in

508 the validation period than in the calibration period as explained by FAR, and had less

509 estimation error in the calibration period than in the validation period as revealed by

510 MBE and RMSE. The values of NSE and $\mathrm{R}^{2}$ for November to June suggest that low

511 portion of the variation in the observed flow can be explained by the variation in the

512 modelled flow. This is partly due to the high falsely detected flow days as shown by

513 FAR. Overall, the model showed better performance in the validation period than in the

514 calibration period using all metrics except RMSE and MBE.

[Table 2 near here]

\section{$516 \quad$ Water supply and hydropower generation in Sudan}

517 This section presents the water supply shortages and hydropower generation in Sudan

518 with the two demand scenarios, the three dam operation scenarios, and the above- and

519 below-normal hydrologic conditions. It was found that the initial reservoir water level

520 of Tekeze-5 has minor impacts on water supply shortages and hydropower generation in

521 Sudan. This was due to the operating policy of Tekeze-5 Dam which is based on a

522 constant power target (see Tables S1 to S3 in the online supplemental data). Therefore, 
523 the results presented herein are only for an intermediate initial water level of the Dam

524 (i.e., $1120 \mathrm{~m}$ asl).

Figures 6.a to 6.d illustrate the probability of exceedance of the annual water supply shortages of Sudan with the current and future water demand scenarios under above and below-normal hydrologic conditions. Figure 6.a reveals that business as usual operation of dams with the current water demands under below-normal hydrologic conditions results in water supply shortages in Sudan that range from 19 to 1,425 Mm3/year. Under the same circumstances, shifting from business as usual to coordination within Sudan reduces the probability of exceedance for the water supply

532 shortages that range between 0 and $175 \mathrm{Mm} 3 /$ year. Moreover, it was found that shifting

533 from coordination within Sudan to sub-basin coordination of dams has low impacts on

534 Sudan's water supply shortages (i.e., slightly reduces the probability of exceedance for 535 the shortages that lie between 610 and $690 \mathrm{Mm} 3 /$ year; see Figure 6.a). Along the same 536 lines, Figure 6.b shows that business as usual operation of dams under above-normal 537 hydrologic conditions and with the current water demands produces supply shortages in 538 Sudan that range from 0 to $182 \mathrm{Mm} 3$ /year with around $10 \%$ probability of exceeding 60

$539 \mathrm{Mm} 3 /$ year. Shifting to coordination within Sudan reduces the maximum annual supply

540 shortages to $8 \mathrm{Mm} 3$ with only $0.3 \%$ probability of having water shortages (Figure 6.b).

541 The evidence from Figure 6.b suggests no difference between supply shortages in the

542 coordination within Sudan and the sub-basin coordination scenarios. On the other hand,

543 a water supply shortage range of 21 to $2,160 \mathrm{Mm} 3 /$ year was found with the future water

544 demand scenario under below-normal hydrologic conditions and business as usual

545 operation of dams (see Figure 6.c). Shifting to coordination within Sudan or sub-basin

546 coordination lessens this range to 0 to $2,070 \mathrm{Mm} 3 /$ year with a $70 \%$ probability of

547 occurrence of water supply shortages compared to a $100 \%$ in the case of business as 
548 usual. Furthermore, Figure 6.d illustrates that business as usual operation of dams under

549 above-normal hydrologic conditions and with the future water demand scenario results

550 in low annual supply shortages that range from 0 to $290 \mathrm{Mm} 3$ with around $10 \%$

551 probability of exceeding $77 \mathrm{Mm} 3 /$ year. Moreover, coordinating the operation of dams

552 within Sudan or across the basin results in nearly similar shortages with around 3.5\%

553 probability occurrence. As Figures 6.a and 6.c show, under below-normal hydrologic

554 conditions, shifting from coordination within Sudan to sub-basin coordination produces

555 minor benefits in terms of reduction in water supply shortages. This result can be

556 explained by the limited storage in Tekeze-5 Reservoir which occurred due to water

557 scarcity in below-normal conditions. Further, Figures 6.b and 6.d also suggest no

558 difference between water supply shortages in the coordination within Sudan and the

559 sub-basin coordination scenarios. This is because the water supply shortages were

560 nearly eliminated in the scenario of coordination within Sudan. The latter finding

561 signals that sub-basin coordination would positively impact water supply in the basin in

562 above-normal conditions should Ethiopia implements its irrigation plans.

563 Regarding hydropower generation in Sudan, the following was noted (see

564 Figures 6.e to 6.h): an insignificant difference in annual energy generation across the

565 three dam operation scenarios; a profound diffrence in daily energy generation across

566 the three dam operation scenarios; a slightly higher annual energy generation with the

567 current demand scenario than with the future demands scenario; a considerably higher

568 annual energy generation under above-normal hydrologic conditions than under below-

569 normal hydrologic conditions. It was found that the annual energy generation of Sudan

570 under below-normal hydrologic conditions (Figures 6.e and 6.g) ranges from 100,000 to

$571 \quad 1,220,000 \mathrm{MWh}$ with a coefficient of variation of around 0.24 . However, this range 
572 increases under above-normal hydrologic conditions (Figures 6.f and 6.h) to between

573865,000 to $1,500,000 \mathrm{MWh}$ with a coefficient of variation of approximately 0.07 .

[Figure 6 near here]

To sum up, shifting from business as usual to coordinated operation of dams

within Sudan decreases the water supply shortages considerably in above- and below-

normal hydrologic conditions and with both water demand scenarios. The three dam

578 operation scenarios have insignificant impacts on the annual energy generation of Sudan

579 and considerable impacts on the daily distribution of energy generation. The annual

energy generation increases significantly in above-normal hydrologic conditions

compared to below-normal hydrologic conditions with less variability in energy

582 generation in the former than the latter.

\section{Hydropower generation in Ethiopia}

584 Figure 7 demonstrates the total annual energy generation of Ethiopia from Tekeze-5

585 Dam under the two demand scenarios, the above and below-normal hydrologic

586 conditions, and the two operation settings of Tekeze-5 Dam. The results presented in

587 Figure 7 are based on a $1120 \mathrm{~m}$ asl initial water level for Tekeze-5 as little difference

588 was found in the results of the six initial reservoir water levels. The evidence from

589 Figure 7 shows that the demand and dam operation scenarios have insignificant impacts

590 on annual and daily energy generation from Tekeze-5 Dam. It was found that energy

591 generation from the dam ranges between 110,000 and 2,370,000 MWh/year in below-

592 normal hydrologic conditions. In above-normal hydrologic conditions, the results show

593 a minimum annual energy generation of around 1,170,000 MWh and a maximum of

594 around 2,370,000 MWh. This increase in the minimum is due to water abundance in

595 above-normal conditions compared to below-normal conditions. It is worth mentioning 
596 that 2,370,000 MWh is the maximum possible amount of energy that could be generated

597 from the dam annually. Figure 7 demonstrates less variability in annual energy

598 generation in above-normal conditions than in below-normal conditions. This variability

599 decrease can be confirmed with a coefficient of variation of 0.06 and 0.4 in the above-

600 and below-normal hydrologic conditions, respectively.

601

[Figure 7 near here]

\section{Conclusions}

603 Coordinated management of water and energy systems is more urgent now than ever

604 especially in arid regions with seasonal, dammed, transboundary rivers. While

605 understanding the uniqueness of each river is key to the sustainable management of

606 water and energy resources (H. Zhang \& Li, 2018), the unavailability/inaccessibility of

607 ground hydrologic and/or meteorological data has for long hindered the optimal

608 management of the two resources. This study explores in-country and transboundary

609 management strategies for water supply and hydropower generation under prolonged

610 above- and below-normal hydrologic conditions for Tekeze-Atbara, a transboundary

611 river between Ethiopia, Eritrea, and Sudan, that suffers a scarcity of ground data

612 (unavailability and inaccessibility). To achieve that, a daily river basin model is

613 developed for Tekeze-Atbara for the period 1984 to 2016 to include hydropower dams,

614 large-scale irrigation schemes, significant domestic water users, and major inflows and

615 water losses. To overcome the data scarcity issue of the study region, satellite-based

616 rainfall and evapotranspiration data are used as inputs to the model. Moreover, satellite

617 imagery is used to estimate reservoir water levels where no data are available. In this

618 study, 36 scenarios are examined across 50 above-normal and 50 below-normal

619 hydrologic conditions that are generated using the bootstrap method. The scenarios 
620 result from combinations of dam operating settings, water demand scenarios, and initial system conditions.

Based on certain scenario assumptions, the results revealed that coordinating the operation of the Sudanese dams in the study area would have positive impacts on irrigation and domestic water supply under both above- and below-normal conditions. Even though this in-country coordination would have insignificant impacts on annual hydro-energy generation in Sudan, it implies changes in daily energy generation which require adjusting the energy mix on the country level. On the other hand, the assumed sub-basin coordination of dam operation resulted in slight improvements in water supply and hydropower generation in the basin compared to coordination within Sudan only. Nevertheless, sub-basin coordination is anticipated to have significant positive

631 impacts in above-normal hydrologic conditions with future irrigation in Ethiopia added to the system. It is important to note that any positive outcomes of coordination would support trust-building between riparian countries which often happens in small steps

634 over a long period (Huisman, Jong, \& Wieriks, 2000; Uitto \& Duda, 2002). Mutual trust 635 is instrumental to international cooperation (Raadgever, Mostert, Kranz, Interwies, \& 636 Timmerman, 2008) especially in a hydro-politically complex basin like the Nile. This study has some limitations that can be addressed by future research.

638 Landsat satellite images were used to estimate the historic water levels of Tekeze-5 639 Reservoir. Landsat has a $30 \mathrm{~m}$ spatial resolution, a 21-day temporal resolution, and a 640 varying cloud cover and sun azimuth. Future studies could use other sources of satellite 641 imagery that have better characteristics and apply cloud and shadow removal techniques 642 (Helmer \& Ruefenacht, 2005; Lin, Tsai, Lai, \& Chen, 2013; Tseng, Tseng, \& Chien, 6432008 ) to enable estimating reservoir water levels more accurately and at finer time 644 intervals. The daily model developed for this study uses monthly evaporation 
645 coefficients to estimate reservoir evaporation and therefore assumes a constant daily

646 evaporation rate for each month. This assumption is used in reality to operate the three

647 dams in Tekeze-Atbara Basin and most dams in the Nile Basin. Notwithstanding this

648 limitation, the daily model developed herein certainly adds value over a monthly model

649 as it simulates several daily processes that inherently impact water supply and

650 hydropower generation (e.g. tailwater level, dam release capacity, dam operating rules)

651 (World Bank, 1980). In this study, the above- and below-normal hydrologic sequences

652 were generated based on the historic river flow record. This approach, however,

653 overlooks the non-stationarity in the climate system which has been revealed by several

654 studies on East Africa as a temperature rise (Nadir Ahmed Elagib, 2010; Nadir Ahmed

655 Elagib \& Mansell, 2000; IPCC, 2008) or a change in precipitation (Shongwe et al.,

656 2011; Souverijns et al., 2016) and river flow (Cole et al., 2014; Gebremicael, Mohamed,

657 Zaag, \& Hagos, 2017; Gizaw, Biftu, Gan, Moges, \& Koivusalo, 2017). Whereas the

658 increase in temperature would increase evaporation and/or transpiration from reservoirs

659 and irrigatted lands, the increase (decrease) in precipitation and river flow would

660 increase (decrease) hydropower generation (Cole et al., 2014) and enhance (negatively

661 affect) water supply. A 20-year length was chosen for the hydrologic sequences to

662 exemplify prolonged conditions. Further research could test hydrologic sequences with

663 different lengths and generate sequences based on climatic projections. Furthermore, the

664 future demand scenario considered herein did not include the agricultural development

665 plans of Ethiopia because little data were available to us about them. Digna et al. (2018)

666 reported a potential irrigation area in Ethiopia of around 45,000 ha that is yet to be

667 exploited. Irrigation water abstractions in Ethiopia would certainly impact water supply

668 and hydropower generation in the basin. While the findings of this study show that

669 raising the level of coordination would produce benefits to water supply, an 
optimisation model is necessary to quantify the full value of coordination. Such an optimisation model should consider future dams and water users in Ethiopia in addition to the economic, social, and environmental impacts of the water infrastructures in the basin. Lastly, the extent of this study was limited to the Tekeze-Atbara Basin to explore possible management approaches for water and energy in the basin. However, it is essential to conduct a similar analysis for the whole Nile Basin to shed light on possible cooperative management approaches on a larger scale. necessitates coordinating the management of river basins. Sustainable and efficient management of water and energy systems should consider all the relevant social, economic, and environmental aspects on the local, national, and regional levels.

Research on innovative management approaches for water and energy resources is highly needed, especially in data-scarce regions.

683

684

685

686

687

688

689

690

691

692

693

694

695

696

\section{Acknowledgements}

The authors would like to thank the Sudan Meteorological Authority, the Ministry of Water Resources, Irrigation, and Electricity of Sudan, and the Eastern Nile Technical Regional Office for supporting this study. Also, thanks to the National Oceanic and Atmospheric

$$
\text { Administration, the University of Reading, the U.S. Geological Survey (USGS), and the }
$$
Climate Hazards Group of the University of California for making the satellite data easily accessible. Moreover, thanks to the Deutscher Akademischer Austauschdienst (DAAD) for funding the M.Sc. research of the second author from which this study benefited.

\section{References}

Abera, F. F., Asfaw, D. H., Engida, A. N., \& Melesse, A. M. (2018). Optimal operation of hydropower reservoirs under climate change: The case of Tekeze reservoir, Eastern Nile. Water, 10(3). https://doi.org/10.3390/w10030273

Abreha, Y. G. (2010). Tradeoff between hydropower generation, environmental flow and irrigation: Tekeze river, Nile River Basin, Ethiopia. UNESCO-IHE Institute for 
697

698

699

700

701

702

703

704

705

706

707

708

709

710

711

712

713

714

715

716

717

718

719

720

721

722

723

724

725

726

727

Water Education.

Adera, A. G. (2015). Hydrological Analysis of Tekeze Hydropower System in the Current and Future Climate. Norwegian University of Science And Technology.

Al-Saidi, M., \& Elagib, N. (2017). Towards understanding the integrative approach of the water, energy and food nexus. Science of the Total Environment, 574(2017), 1131-1139. https://doi.org/10.1016/j.scitotenv.2016.09.046

Amekawa, Y. (2009). Reflections on the growing influence of good agricultural practices in the Global South. Journal of Agricultural and Environmental Ethics, 22(6), 531-557. https://doi.org/10.1007/s10806-009-9171-8

Arjoon, D., Mohamed, Y., Goor, Q., \& Tilmant, A. (2014). Hydro-economic risk assessment in the eastern Nile River basin. Water Resources and Economics, 8, 16-31. https://doi.org/10.1016/j.wre.2014.10.004

Ashouri, H., Hsu, K., Sorooshian, S., Braithwaite, D., Knapp, K., Cecil, D., ... Prat, O. (2015). PERSIANN-CDR: Daily precipitation climate data record from multisatellite observations for hydrological and climate studies. Bulletin of the American Meteorological Society, 96(1), 69-83. https://doi.org/10.1175/BAMS-D$13-00068.1$

Basheer, M., \& Elagib, N. A. (2018a). Performance of satellite-based and GPCC 7.0 rainfall products in an extremely data-scarce country in the Nile Basin. Atmospheric Research, 215(1 January 2019), 128-140. https://doi.org/10.1016/j.atmosres.2018.08.028

Basheer, M., \& Elagib, N. A. (2018b). Sensitivity of Water-Energy Nexus to dam operation: A Water-Energy Productivity concept. Science of The Total Environment, 616-617(March 2018), 918-926. https://doi.org/10.1016/j.scitotenv.2017.10.228

Basheer, M., Wheeler, K. G., Ribbe, L., Majdalawi, M., Abdo, G., \& Zagona, E. A. (2018). Quantifying and evaluating the impacts of cooperation in transboundary river basins on the Water-Energy-Food nexus: The Blue Nile Basin. Science of the Total Environment, 630, 1309-1323. https://doi.org/10.1016/j.scitotenv.2018.02.249

Bazilian, M., Rogner, H., Howells, M., Hermann, S., Arent, D., Gielen, D., ... 
728

729

730

731

732

733

734

735

736

737

738

739

740

741

742

743

744

745

746

747

748

749

750

751

752

753

754

755

756

757

758

Yumkella, K. (2011). Considering the energy, water and food nexus: Towards an integrated modelling approach. Energy Policy, 39(12), 7896-7906.

https://doi.org/10.1016/j.enpol.2011.09.039

Beck, H. ., Zimmermann, N. E., McVicar, T. R., Vergopolan, N., Berg, A., \& Wood, E. F. (2018). Present and future Köppen-Geiger climate classification maps at 1-km resolution. Scientific Data. https://doi.org/10.1038/sdata.2018.214

Beck, H. E., Dijk, A. I. J. M. Van, Levizzani, V., Schellekens, J., \& Miralles, D. G. (2017). MSWEP: 3-hourly 0.25॰ global gridded precipitation (1979-2015) by merging gauge, satellite, and reanalysis data. Hydrology and Earth System Sciences, 589-615. https://doi.org/10.5194/hess-21-589-2017

Block, P., \& Strzepek, K. (2010). Economic Analysis of Large-Scale Upstream River Basin Development on the Blue Nile in Ethiopia Considering Transient Conditions, Climate Variability, and Climate Change. Journal of Water Resources Planning and Management, 136(2), 156-166. https://doi.org/10.1061/(ASCE)WR.1943-5452.0000022

Boadi, S. A., \& Owusu, K. (2017). Impact of climate change and variability on hydropower in Ghana. African Geographical Review. https://doi.org/10.1080/19376812.2017.1284598

Chirisa, I., \& Bandauko, E. (2015). African Cities and the Water-Food-Climate-Energy Nexus: an Agenda for Sustainability and Resilience at a Local Level. Urban Forum, 26, 391-404. https://doi.org/10.1007/s12132-015-9256-6

Cole, M. A., Elliott, R. J. R., \& Strobl, E. (2014). Climate change, hydro-dependency, and the african dam boom. World Development, 60, 84-98. https://doi.org/10.1016/j.worlddev.2014.03.016

Digna, R. F., Castro-Gama, M. E., van der Zaag, P., Mohamed, Y. A., Corzo, G., \& Uhlenbrook, S. (2018). Optimal operation of the Eastern Nile System using Genetic Algorithm, and benefits distribution of water resources development. Water (Switzerland), 10(7). https://doi.org/10.3390/w10070921

Digna, R. F., Mohamed, Y. A., van der Zaag, P., Uhlenbrook, S., \& Corzo, G. A. (2017). Nile River Basin modelling for water resources management - a literature review. International Journal of River Basin Management, 15(1), 39-52. 
https://doi.org/10.1080/15715124.2016.1228656

760 Ebtehaj, M., Moradkhani, H., \& Gupta, H. V. (2010). Improving robustness of hydrologic parameter estimation by the use of moving block bootstrap resampling. Water Resources Research, 46, 1-14. https://doi.org/10.1029/2009WR007981

Elagib, N. A. (2010). Trends in intra-and inter-annual temperature variabilities across

Elagib, N. A., \& Mansell, M. G. (2000). Recent trends and anomalies in mean seasonal

G. Allen, R., Pereira, L. S., Raes, D., \& Smith, M. (1998). FAO Irrigation and and annual temperatures over Sudan. Journal of Arid Environments, 45(3), 263288. https://doi.org/10.1006/jare.2000.0639

Engström, R. E., Howells, M., Destouni, G., Bhatt, V., Bazilian, M., \& Rogner, H. H. (2017). Connecting the resource nexus to basic urban service provision - with a focus on water-energy interactions in New York City. Sustainable Cities and Society, 31, 83-94. https://doi.org/10.1016/j.scs.2017.02.007

FAO. (2014). The Water-Energy-Food Nexus at FAO: Concept Note. Retrieved from http://www.gwp.org/PageFiles/4/The Water-Energy-Food Nexus at FAO - Concept Note (FAO, 2014).pdf

FAO. (2015). CropWat. Retrieved November 30, 2016, from http://www.fao.org/nr/water/infores_databases_cropwat.html

Funk, C., Peterson, P., Landsfeld, M., Pedreros, D., Verdin, J., Rowland, J., ... Verdin, A. (2014). A Quasi-Global Precipitation Time Series for Drought Monitoring. U.S. Geological Survey Data Series, 832, 4. https://doi.org/http://dx.doi.org/110.3133/ds832 Drainage Paper: Crop Evapotranspiration. Rome. 
790 García-Vera, M. Á. (2013). The application of hydrological planning as a climate

791

792

793

794

795

796

797

798

799

800

801

802

803

804

805

806

807

808

809

810

811

812

813

814

815

816

817

818

819

820 change adaptation tool in the Ebro basin. International Journal of Water Resources Development, 29(2), 219-236. https://doi.org/10.1080/07900627.2012.747128

Gebremicael, T. G., Mohamed, Y. A., Zaag, P. V., \& Hagos, E. Y. (2017). Temporal and spatial changes of rainfall and streamflow in the Upper Tekezē-Atbara river basin, Ethiopia. Hydrology and Earth System Sciences, 21(4), 2127-2142. https://doi.org/10.5194/hess-21-2127-2017

Gizaw, M. S., Biftu, G. F., Gan, T. Y., Moges, S. A., \& Koivusalo, H. (2017). Potential impact of climate change on streamflow of major Ethiopian rivers. Climatic Change, 143(3-4), 371-383. https://doi.org/10.1007/s10584-017-2021-1

Goor, Q., Halleux, C., Mohamed, Y., \& Tilmant, A. (2010). Optimal operation of a multipurpose multireservoir system in the Eastern Nile River Basin. Hydrology and Earth System Sciences, 14, 1895-1908. https://doi.org/10.5194/hess-14-18952010

Grieser, J., Gommes, R., \& Bernardi, M. (2006). New LocClim - the Local Climate Estimator of FAO. Geophysical Research Abstracts, 8(1), 08305. Retrieved from http://www.juergen-grieser.de/publications/publications_pdf/EGU06-J-08305.pdf

Guariso, G., Haynes, K. E., Whittington, D., \& Younis, M. (1981). A Real-Time Management Model for the Aman High Dam with Policy Implications. Geographical Analysis, 13(4), 355-372.

Guariso, G., \& Whittington, D. (1987). Implications of Ethiopian water development for Egypt and Sudan. International Journal of Water Resources Development, 3(2), 105-114. https://doi.org/10.1080/07900628708722338

HEC. (2000). Hydrologic Modeling System HEC-HMS Technical Reference Manual. Washington. Retrieved from http://www.hec.usace.army.mil/software/hechms/documentation.aspx

Helmer, E. H., \& Ruefenacht, B. (2005). Cloud-Free Satellite Image Mosaics with Regression Trees and Histogram Matching. Photogrammetric Engineering \& Remote Sensing, 71(9), 1079-1089. https://doi.org/10.14358/PERS.71.9.1079

Hirabayashi, Y., Kanae, S., Emori, S., Oki, T., \& Kimoto, M. (2008). Global projections 59 60 of changing risks of floods and droughts in a changing climate. Hydrological 
821

822

823

824

825

826

827

828

829

830

831

832

833

834

835

836

837

838

839

840

841

842

843

844

845

846

847

848

849

850

Sciences Journal, 53(4), 754-772. https://doi.org/10.1623/hysj.53.4.754

Huisman, P., Jong, J. de, \& Wieriks, K. (2000). Transboundary cooperation in shared river basins: experiences from the Rhine, Meuse and North Sea. Water Policy, 2, 83-97. https://doi.org/10.1016/S1366-7017(99)00023-9

Institute of Hydrology. (1978). A report on the present and future availability of water for irrigation and power in Khashm el Girba reservoir. Wallingford. Retrieved from http://nora.nerc.ac.uk/id/eprint/507638/1/N507638CR.pdf

IPCC. (2008). Technical Paper On Climate Change And Water. Budapest. Retrieved from https://www.ipcc.ch/meetings/session28/doc13.pdf

Jarvis, A., Reuter, H., Nelson, A., \& Guevara, E. (2008). Hole-filled SRTM for the globe Version 4. Retrieved December 30, 2018, from http://srtm.csi.cgiar.org

Jeuland, M. (2010). Economic implications of climate change for infrastructure planning in transboundary water systems: An example from the Blue Nile. Water Resources Research, 46(11), 1-19. https://doi.org/10.1029/2010WR009428

Jeuland, M., Wu, X., \& Whittington, D. (2017). Infrastructure development and the economics of cooperation in the Eastern Nile. Water International, 1-21. https://doi.org/10.1080/02508060.2017.1278577

King, A., \& Block, P. (2014). An assessment of reservoir filling policies for the Grand Ethiopian Renaissance Dam. Journal of Water and Climate Change, 5(2), 233243. https://doi.org/10.2166/wcc.2014.043

Kurian, M. (2017). The water-energy-food nexus Trade-offs, thresholds and transdisciplinary approaches to sustainable development. Environmental Science and Policy, 68, 97-106. https://doi.org/10.1016/j.envsci.2016.11.006

Larsen, M. A. D., \& Drews, M. (2019). Water use in electricity generation for waterenergy nexus analyses: The European case. Science of the Total Environment, 651, 2044-2058. https://doi.org/10.1016/j.scitotenv.2018.10.045

Lee, Y., Yoon, T., \& Shah, F. A. (2012). Optimal Watershed Management for Reservoir Sustainability: Economic Appraisal. Journal of Water Resources Planning and Management, 139(2), 129-138. https://doi.org/10.1061/(asce)wr.19435452.0000232 
851 Levy, B., \& Baecher, G. (1999). NileSim: A Windows-Based Hydrologic Simulator of 852 the Nile River Basin. Journal of Water Resources Planning and Management, 125(2), 100-106. https://doi.org/10.1061/(ASCE)0733-9496(1999)125:2(100)

Lin, C., Tsai, P., Lai, K., \& Chen, J. (2013). Cloud Removal From Multitemporal Satellite Images Using Information Cloning. IEEE Transactions on Geoscience and Remote Sensing, 51(1), 232-241. https://doi.org/10.1109/TGRS.2012.2197682

Lindström, A., \& Granit, J. (2012). Large-scale water storage in the water, energy and food nexus Perspectives on benefits, risks and best practices. Retrieved from www.siwi.org/wp-content/uploads/2015/09/Water_Storage_Paper_21.pdf

Liu, J., Yang, H., Cudennec, C., Gain, A. K., Hoff, H., Lawford, R., ... Zheng, C. (2017). Challenges in operationalizing the water-energy-food nexus. Hydrological Sciences Journal, 62(11), 1714-1720. https://doi.org/10.1080/02626667.2017.1353695

McCartney, M. P., \& Menker Girma, M. (2012). Evaluating the downstream implications of planned water resource development in the Ethiopian portion of the Blue Nile River. Water International, 37(4), 362-379. https://doi.org/10.1080/02508060.2012.706384

Mekonnen, D. F., Duan, Z., Rientjes, T., \& Disse, M. (2018). Analysis of combined and isolated effects of land-use and land-cover changes and climate change on the upper Blue Nile River basin's streamflow. Hydrology and Earth System Sciences, 22(12), 6187-6207. https://doi.org/10.5194/hess-22-6187-2018

Modarres, R. (2007). Streamflow drought time series forecasting. Stochastic Environmental Research and Risk Assessment, 21(3), 223-233. https://doi.org/10.1007/s00477-006-0058-1

Møller, L. R., Drews, M., \& Larsen, M. A. D. (2017). Simulation of Optimal DecisionMaking Under the Impacts of Climate Change. Environmental Management, 60, 104-117. https://doi.org/10.1007/s00267-017-0852-1

881 Mulat, A. G., Moges, S. A., \& Moges, M. A. (2018). Evaluation of multi-storage 
882

883

884

885

886

887

888

889

890

891

892

893

894

895

896

897

898

899

900

901

902

903

904

905

906

907

908

909

910

911

912

hydropower development in the upper Blue Nile River (Ethiopia): regional perspective. Journal of Hydrology, 16(February), 1-14.

https://doi.org/10.1016/j.ejrh.2018.02.006

NBI. (2012). State of the River Nile Basin 2012. Entebbe. Retrieved from http://nileis.nilebasin.org/content/state-river-nile-basin-report

Noguchi, K., Gel, Y. R., \& Duguay, C. R. (2011). Bootstrap-based tests for trends in hydrological time series, with application to ice phenology data. Journal of Hydrology, 410(3-4), 150-161. https://doi.org/10.1016/j.jhydrol.2011.09.008

Novella, N., \& Thiaw, W. (2013). African rainfall climatology version 2 for famine early warning systems. Journal of Applied Meteorology and Climatology, 52, 588 606. https://doi.org/10.1175/JAMC-D-11-0238.1

Peng, Y., Xu, W., \& Liu, B. (2016). Considering precipitation forecasts for real-time decision-making in hydropower operations. International Journal of Water Resources Development, 33(6). https://doi.org/10.1080/07900627.2016.1219942

Pradhan, N. S., Sijapati, S., \& Bajracharya, S. R. (2015). Farmers' responses to climate change impact on water availability: insights from the Indrawati Basin in Nepal. International Journal of Water Resources Development. Taylor \& Francis. https://doi.org/10.1080/07900627.2015.1033514

R Core Team. (2015). R: A Language and Environment for Statistical Computing. Retrieved June 27, 2017, from at: https:/www.R-project.org/

Raadgever, G. T., Mostert, E., Kranz, N., Interwies, E., \& Timmerman, J. G. (2008). Assessing management regimes in transboundary river basins: Do they support adaptive management? Ecology and Society, 13(1). Retrieved from https://www.ecologyandsociety.org/vol13/iss 1/art14/

Salman, S. (2016). The Grand Ethiopian Renaissance Dam: the road to the declaration of principles and the Khartoum document. Water International, 41(4), 512-527. https://doi.org/10.1080/02508060.2016.1170374

Satti, S., Zaitchik, B., \& Siddiqui, S. (2015). The question of Sudan: a hydro-economic optimization model for the Sudanese Blue Nile. Hydrology and Earth System Sciences, 19, 2275-2293. https://doi.org/10.5194/hess-19-2275-2015 
913

914

915

916

917

918

919

920

921

922

923

924

925

926

927

928

929

930

931

932

933

934

935

936

937

938

939

940

941

942

943

Projected changes in mean and extreme precipitation in Africa under global warming. Part II: East Africa. Journal of Climate, 24(14), 3718-3733. https://doi.org/10.1175/2010JCLI2883.1

Sloff, C. J., Omer, A. Y. A., Heynert, K. V, \& Mohamed, Y. A. (2015). Design and modeling of reservoir operation strategies for sediment management. In 9th Symposium on River, Coastal and Estuarine Morphodynamics, Iquitos. Peru. Retrieved from https://repository.tudelft.nl/islandora/object/uuid:6c971342-7acf4bd6-8379-50a93a38a0d4?collection=research

Souverijns, N., Thiery, W., Demuzere, M., \& Lipzig, N. P. M. Van. (2016). Drivers of future changes in East African precipitation. Environmental Research Letters, 11(11). https://doi.org/10.1088/1748-9326/11/11/114011

Stamou, A., \& Rutschmann, P. (2018). Pareto Optimization of Water Resources Using the Nexus Approach. Water Resources Management. https://doi.org/10.1007/s11269-018-2127-x

Stedinger, J. R., Sule, B. F., \& Loucks, D. P. (1984). Stochastic dynamic programming models for reservoir operation optimization. Water Resources Research, 20(11), 1499-1505. https://doi.org/10.1029/WR020i011p01499

Stern, M., Flint, L., Minear, J., Flint, A., \& Wright, S. (2016). Characterizing Changes in Streamflow and Sediment Supply in the Sacramento River Basin, California, Using Hydrological Simulation Program-FORTRAN (HSPF). Water, 432(8), $1-$ 21. https://doi.org/10.3390/w8100432

Stern, N. (2006). Stern Review: The Economics of Climate Change. London. Retrieved from http://unionsforenergydemocracy.org/wpcontent/uploads/2015/08/sternreview_report_complete.pdf

Sudanese Hydro Generation Co Ltd. (2011). Khashm Algirba Dam. Retrieved October 21, 2018, from https://archive.is/20130411191603/http://www.shgcsd.com/khashm-dam.html\#selection-165.0-165.18

Sutcliffe, J., \& Parks, Y. (1999). The Hydrology of the Nile. (H. Salz \& Z. W. Kundzewicz, Eds.), IAHS Special Publication. Wallingford: The International Association of Hydrological Science. Retrieved from www.hydrosciences.fr/sierem/produits/biblio/hydrology of the Nile.pdf 
944 Tarnavsky, E., Grimes, D., Maidment, R., Black, E., Allan, R., Stringer, M., ...

945

946

947

948

949

950

951

952

953

954

955

956

957

958

959

960

961

962

963

964

965

966

967

968

969

970

971

972

973

974 Kayitakire, F. (2014). Extension of the TAMSAT satellite-based rainfall monitoring over Africa and from 1983 to present. Journal of Applied Meteorology and Climatology, 53(12), 2805-2822. https://doi.org/10.1175/JAMC-D-14-0016.1

Tekeze Inauguration Bulletin. (2009). Overview of Tekeze hydroelectric power plant. Retrieved from https://docplayer.net/12125895-Overview-of-tekeze-hydroelectricpower-plant-general.html

Tseng, D. C., Tseng, H. T., \& Chien, C. L. (2008). Automatic cloud removal from multi-temporal SPOT images. Applied Mathematics and Computation, 205(2), 584-600. https://doi.org/10.1016/j.amc.2008.05.050

Uitto, J. I., \& Duda, A. M. (2002). Management of transboundary water resources: lessons from international cooperation for conflict prevention. The Geographical Journal, 168(4), 365-378. Retrieved from https://www.jstor.org/stable/3451478

UN. (2017). World Population Prospects: The 2017 Revision. Volume II: Demographic Profiles (ST/ESA/SER.A/400).

UN. (2018). World Urbanization Prospects: The 2018 Revision. New York.

UNDP. (2018). Human Development Indices and Indicators: 2018 Statistical Update. New York.

Welde, K. (2016). Identification and prioritization of subwatersheds for land and water management in Tekeze dam watershed, Northern Ethiopia. International Soil and Water Conservation Research, 4(1), 30-38. https://doi.org/10.1016/j.iswcr.2016.02.006

Wheeler, K. G., Basheer, M., Mekonnen, Z., Eltoum, S., Mersha, A., Abdo, G., ... Dadson, S. (2016). Cooperative filling approaches for the Grand Ethiopian Renaissance Dam. Water International, 8060(May), 1-24. https://doi.org/10.1080/02508060.2016.1177698

Wheeler, K. G., Hall, J. W., Abdo, G. M., Dadson, S. J., Kasprzyk, J. R., Smith, R., \& Zagona, E. A. (2018). Exploring Cooperative Transboundary River Management Strategies for the Eastern Nile Basin. Water Resources Research, 9224-9254. https://doi.org/10.1029/2017WR022149 

prospects for cooperation on the eastern nile. Water Policy, 16(4), 595-608. https://doi.org/10.2166/wp.2014.011

977

Whittington, D., Wu, X., \& Sadoff, C. (2005). Water resources management in the Nile 978 basin: the economic value of cooperation. Water Policy, 7(3), 227-252. https://doi.org/10.2166/wp.2005.0015

World Bank. (1980). New Halfa irrigation rehabilitation project.

Zaghloul, S., El-Moattassem, M., \& Rady, A. (2007). The hydrological interactions between Atbara River and the Main Nile at the confluence area. In the International Congress of River Basin Management (pp. 787-799). Antalya. https://doi.org/10.1002/hyp.6956

Zagona, E., Fulp, T., Shane, R., Magee, T., \& Morgan, H. (2001). Riverware : a Generalized Tool for Complex Reservoir System Modeling. Journal of the American Water Resources Association, 37(4), 913-929.

Zhang, H., \& Li, M. (2018). A process-based framework to examine China's approach to transboundary water management. International Journal of Water Resources Development, 34(5), 705-731. https://doi.org/10.1080/07900627.2018.1476225

Zhang, Y., Block, P., Hammond, M., \& King, A. (2015). Ethiopia's Grand Renaissance Dam: Implications for downstream riparian countries. Journal of Water Resources 
Table 1. Main characteristics of dams located in the study area.

\begin{tabular}{|c|c|c|c|}
\hline Characteristic & KED & UASDC & Tekeze-5 \\
\hline Full supply level (m asl) & 474 & 521 & 1,140 \\
\hline $\begin{array}{l}\text { Minimum Operating Level } \\
\text { (m asl) }\end{array}$ & 463 & 509 & 1,096 \\
\hline Total storage volume (MCM) & 628 (in 1990) & 3,687 (in 2015) & 9,293 (in 2016) \\
\hline Surface Area at FSL $\left(\mathrm{km}^{2}\right)$ & 100 & 302 & 156.9 \\
\hline Surface area at MOL $\left(\mathrm{km}^{2}\right)$ & 8 & 128 & 88.5 \\
\hline $\begin{array}{l}\text { Installed power capacity } \\
\text { (MW) }\end{array}$ & 16 & 320 & 300 \\
\hline Purpose & $\begin{array}{l}\text { Seasonal storage for } \\
\text { hydropower generation } \\
\text { and water supply }\end{array}$ & $\begin{array}{l}\text { Seasonal storage for } \\
\text { hydropower generation } \\
\text { and water supply }\end{array}$ & $\begin{array}{l}\text { Multi-year storage } \\
\text { for hydropower } \\
\text { generation }\end{array}$ \\
\hline
\end{tabular}

Note: KED $=$ Khashm Elgirba Dam; UASDC $=$ Upper Atbara and Setit Dam Complex; FSL $=$ Full Supply Level; MOL = Minimum Operating Level.

Data sources: The Ministry of Water Resources, Irrigation, and Electricity of Sudan and the Eastern Nile Technical Regional Office. 
Table 2. Model performance metrics in the calibration and validation periods.

\begin{tabular}{|l|l|l|l|}
\hline Months & Performance metric & Calibration & Validation \\
\hline \multirow{4}{*}{$\begin{array}{l}\text { July to } \\
\text { October }\end{array}$} & NSE & 0.71 & \\
\cline { 2 - 4 } & $\mathrm{R}^{2}$ & 0.72 & 0.84 \\
\cline { 2 - 4 } & MBE (Mm3/day) & 1.96 & 0.74 \\
\cline { 2 - 4 } & RMSE (Mm3/day) & 52.39 & 21.28 \\
\cline { 2 - 4 } & POD & 0.92 & 61.35 \\
\cline { 2 - 4 } & FAR & 0.14 & 0.95 \\
\hline \multirow{3}{*}{$\begin{array}{l}\text { Novembe June } \\
\text { NSE }\end{array}$} & RSE & 0.18 & 0.02 \\
\cline { 2 - 4 } & MBE (Mm3/day) & 0.22 & 0.37 \\
\cline { 2 - 4 } & RMSE (Mm3/day) & -0.38 & 6.35 \\
\cline { 2 - 4 } & POD & 0.52 & 12.12 \\
\cline { 2 - 4 } & FAR & 0.66 & 0.83 \\
\hline
\end{tabular}

Note: NSE $=$ Nash-Sutcliffe coefficient of efficiency; $\mathrm{R}^{2}=$ coefficient of determination; $\mathrm{MBE}=$ Mean Bias Error; RMSE $=$ Root Mean Square Error; POD = Probability Of Detection; FAR = False Alarm Ratio. 


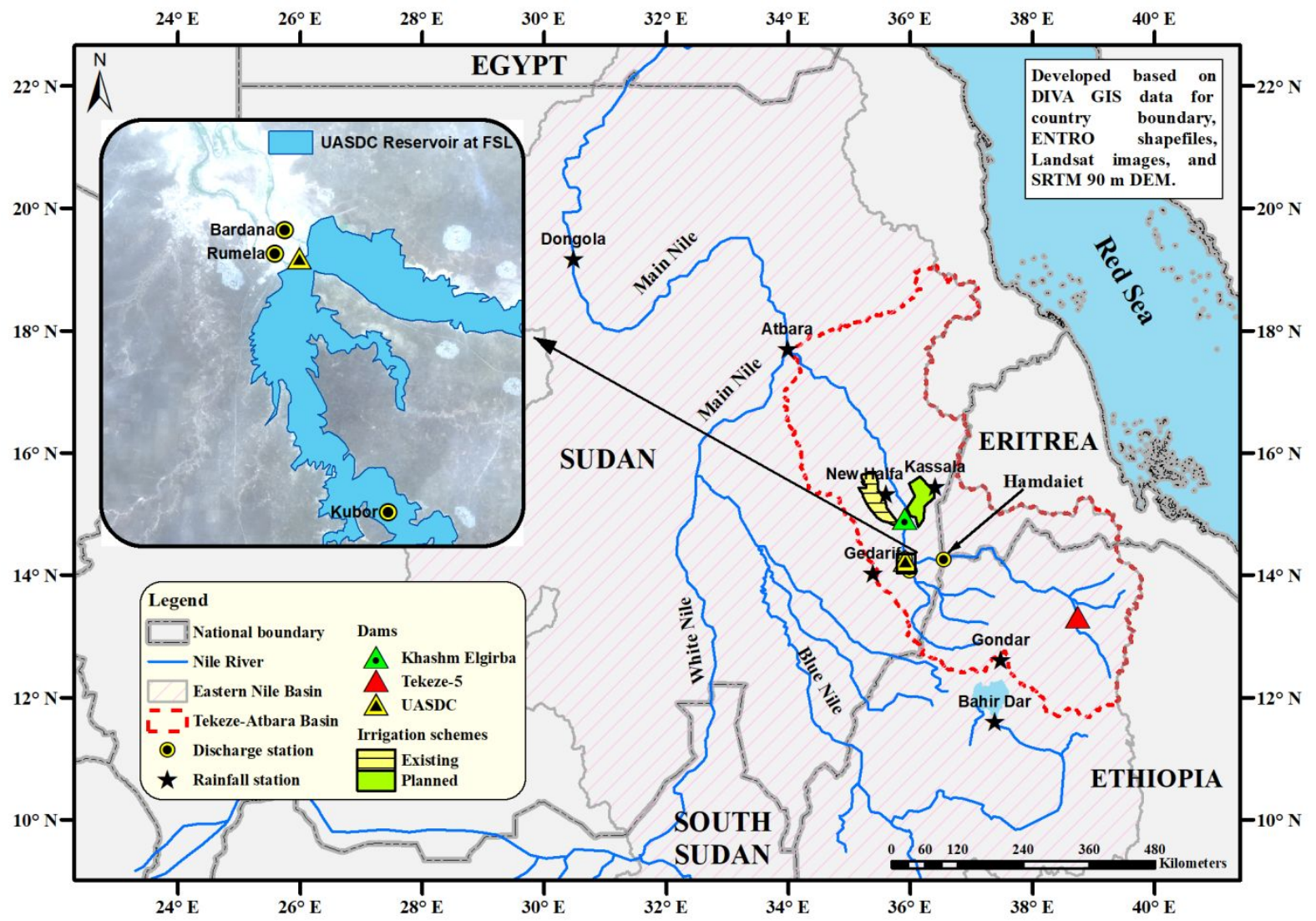

Figure 1. Topography, dams, irrigation schemes, and rainfall and discharge stations in the study area.

Note: UASDC = Upper Atbara and Setit Dam Complex; GIS=Geographic Information System; ENTRO = Eastern Nile Technical Regional Office; SRTM=Shuttle Radar Topography Mission; DEM=Digital Elevation Model; FSL = Full Supply Level. 

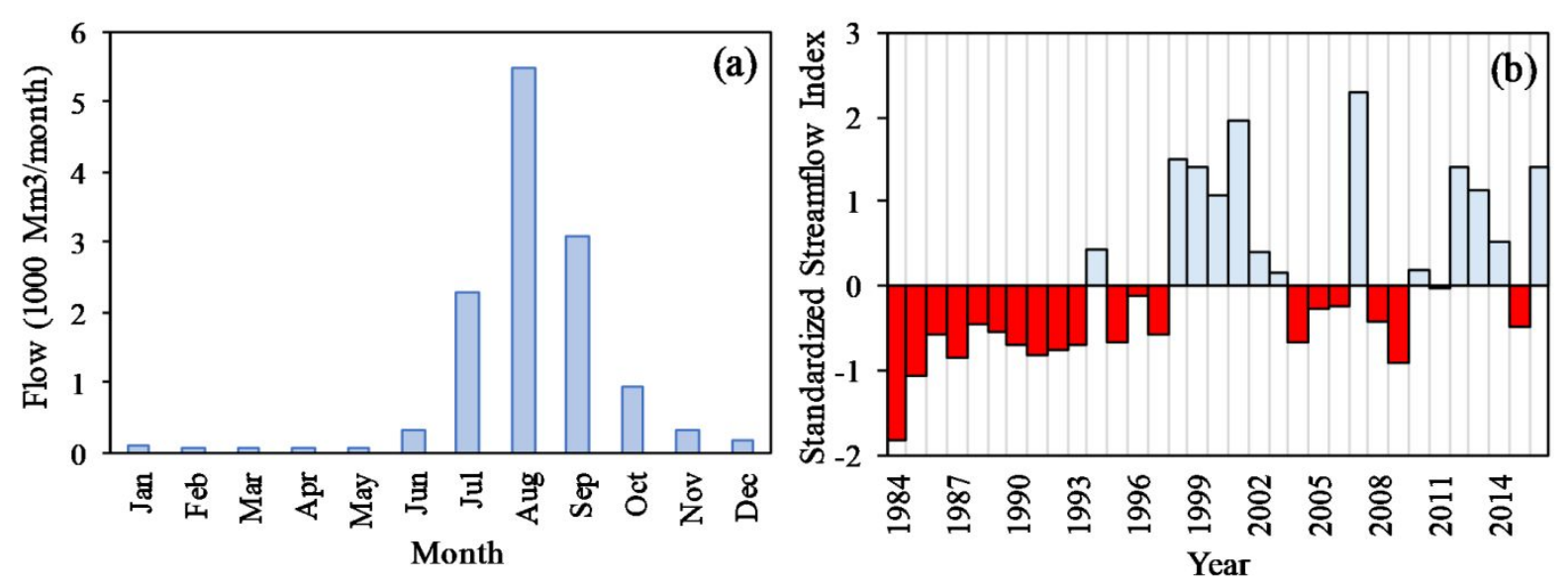

Figure 2. Tekeze-Atbara flow volume over the period 1984 to 2016: (a) average monthly (b) annual Standardized Streamflow Index (SSFI; Modarres (2007)). 


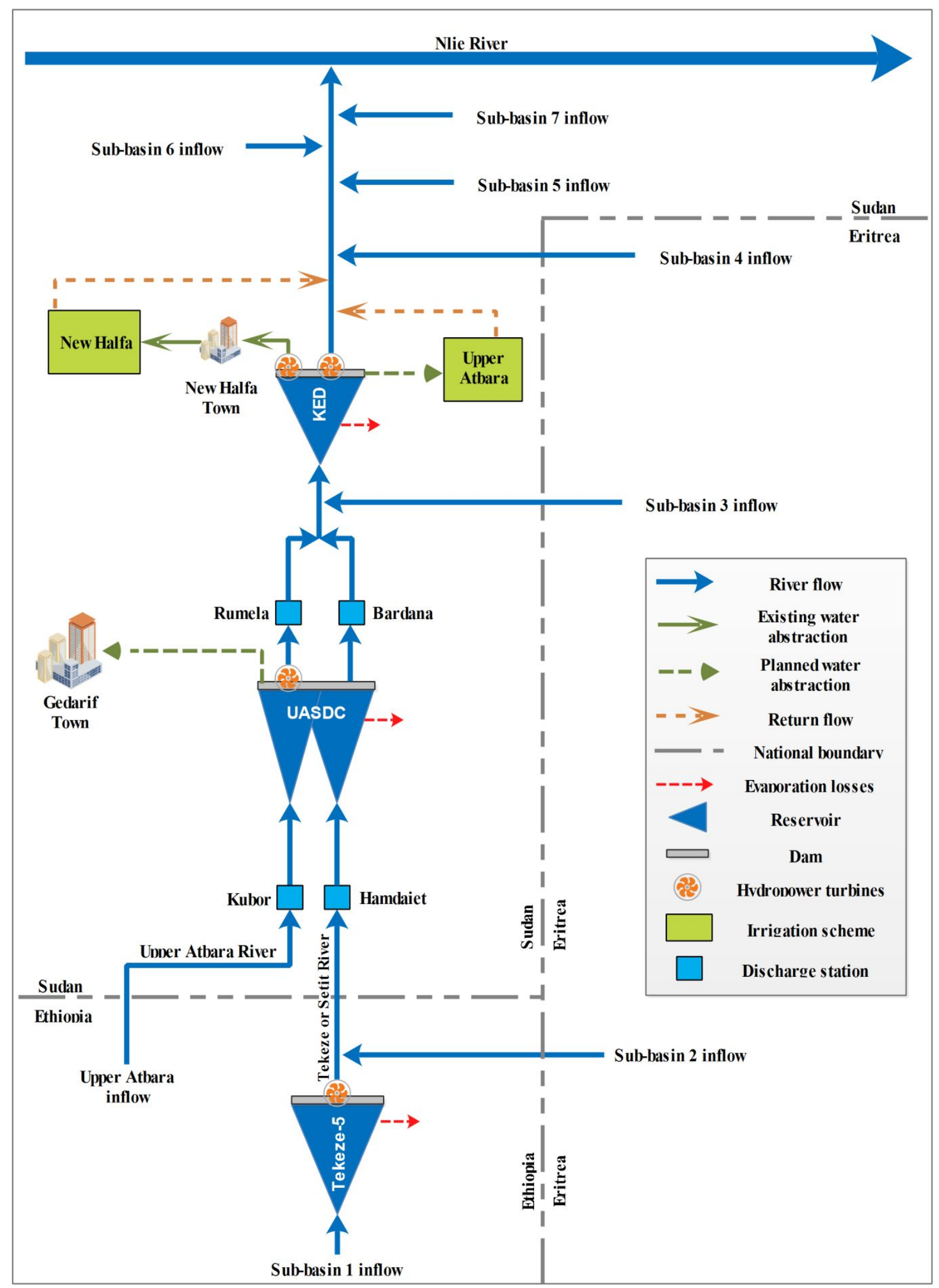

Figure 3. Schematic of the model developed for the study area.

Note: UASDC = Upper Atbara and Setit Dam Complex; KED = Khashm Elgirba Dam 


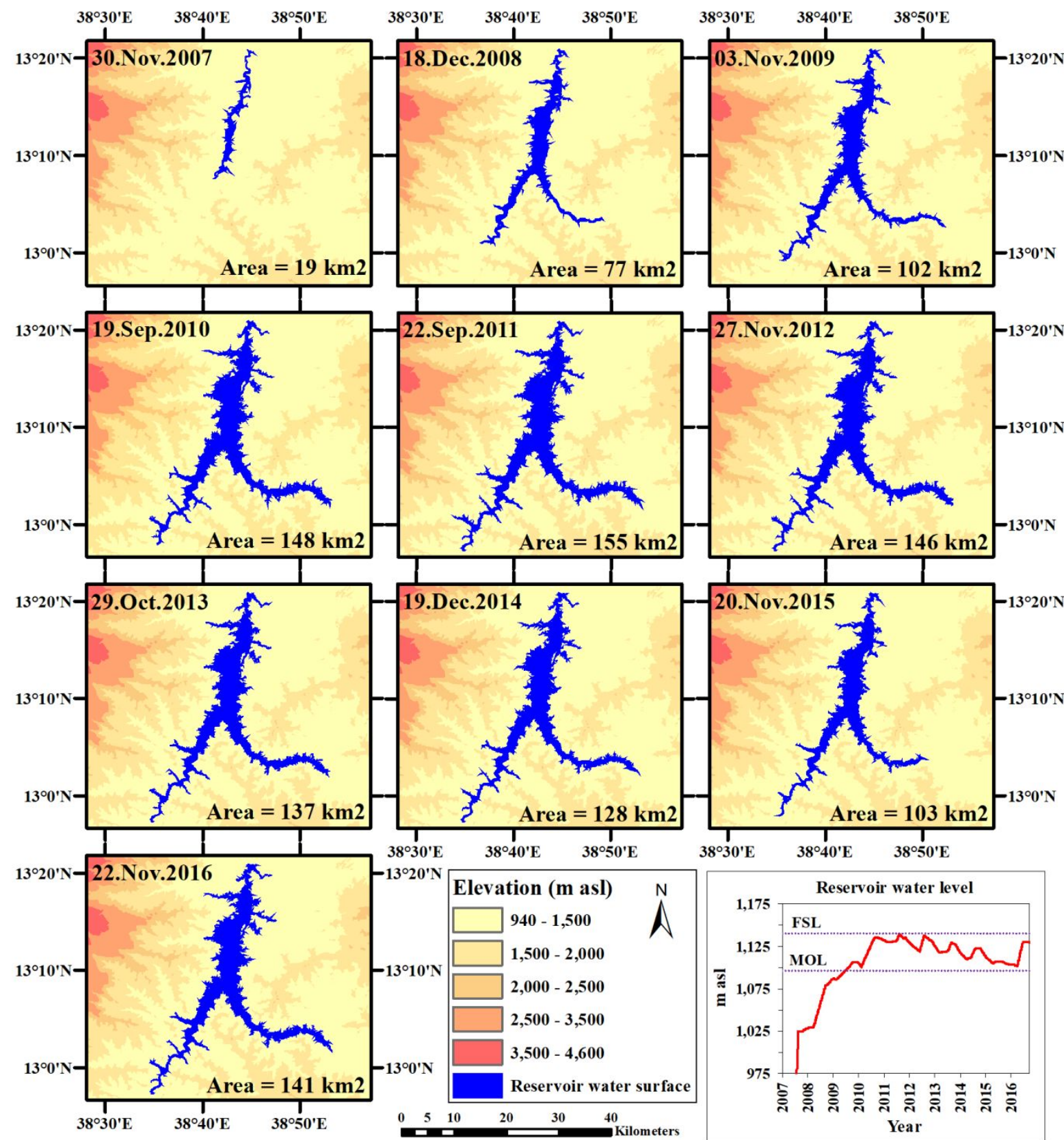

Figure 4. Reservoir surface area of Tekeze-5. The sub-figure in the bottom right corner shows a time series of the reservoir water level from the commencement of the filling until the end of 2016. The displayed data are based on Landsat satellite images.

Note: $\mathrm{MOL}=$ Minimum Operating Level; FSL = Full Supply Level 

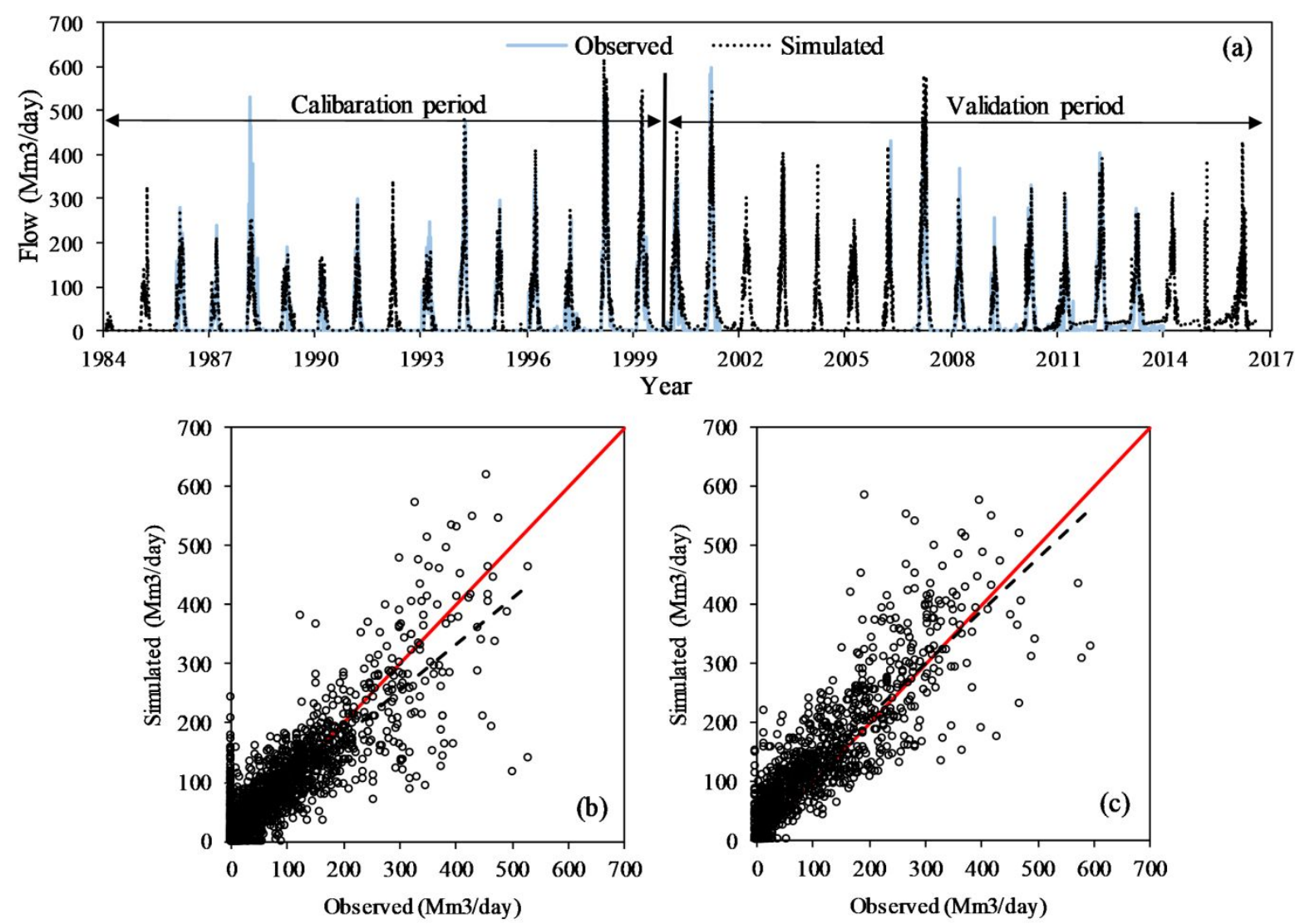

Figure 5. Daily observed and simulated outflow from Khashm Elgirba Dam: (a) time series of the calibration and validation periods (b) scatterplot of the calibration period (c) scatterplot of the validation period. In figures $b$ and c, the continuous and dashed lines represent the 1:1 and regression lines, respectively. 
-- Business as usual
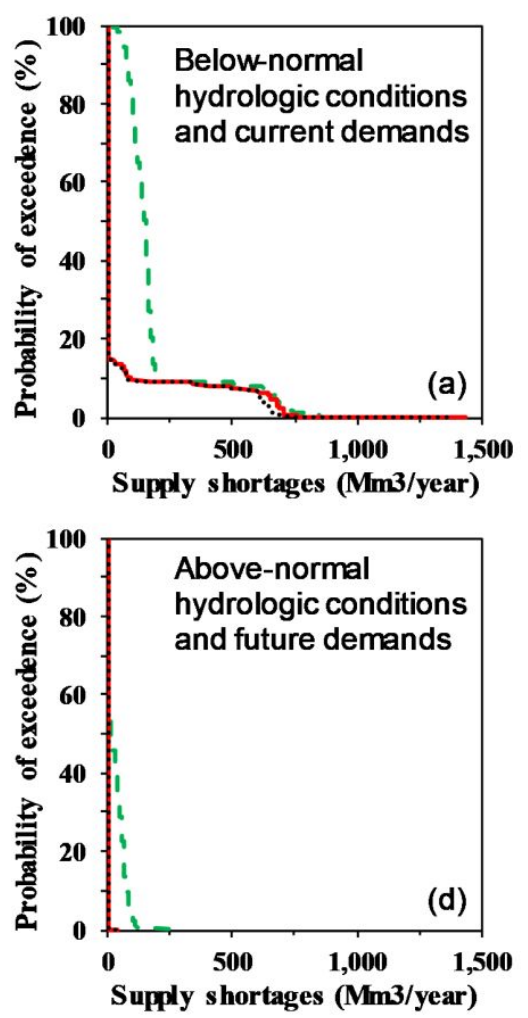

Coordination within Sudan
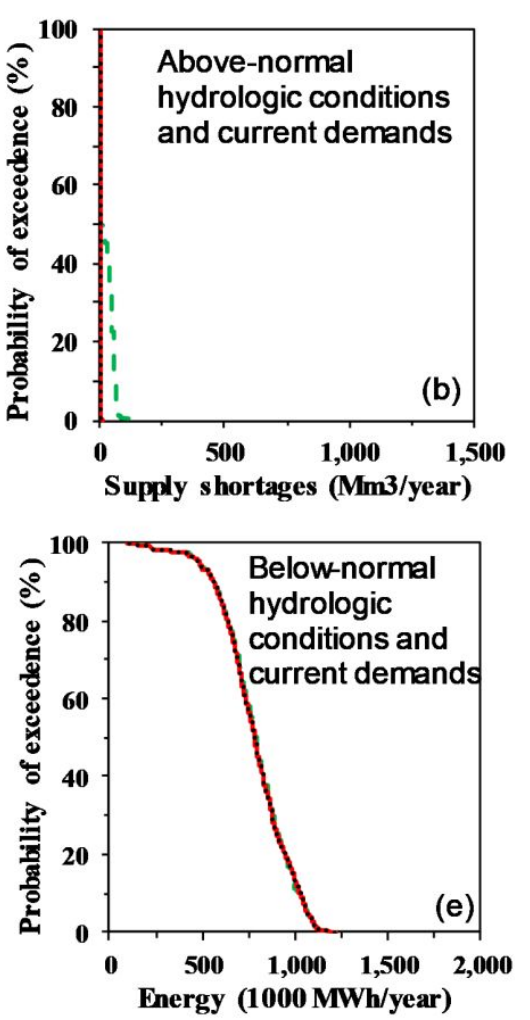

Sub-basin coordination
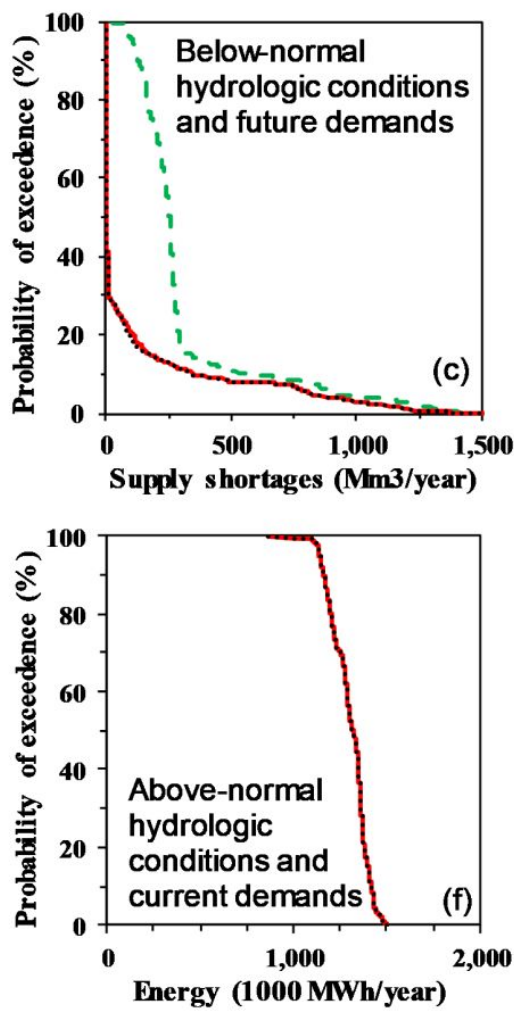
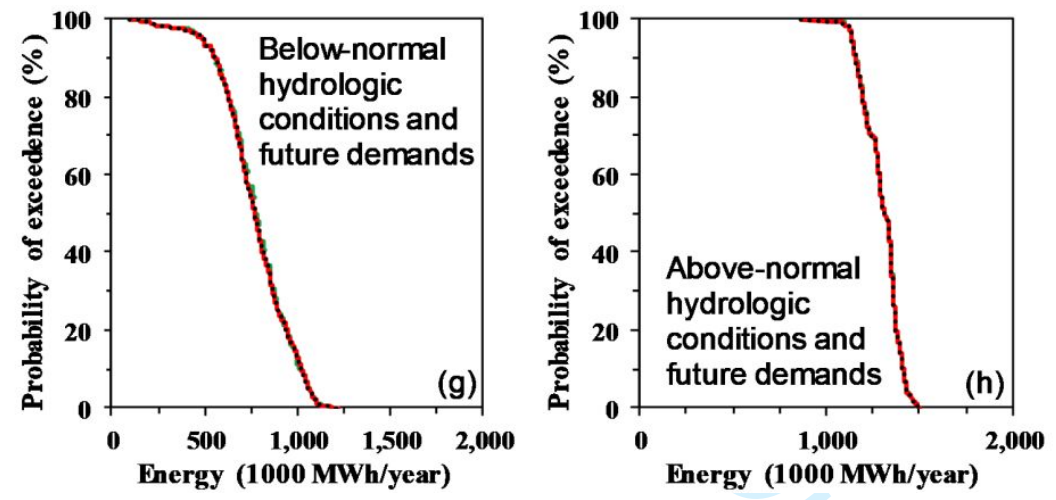

Figure 6. Sudan's annual water supply shortages and energy generation with different dam operation scenarios and Tekeze-5 Dam starting at $1120 \mathrm{~m}$ asl: (a), (b), (c), and (d) probability of exceedance of water supply shortages and (e), (f), (g), and (h) probability of exceedance of energy generation. 

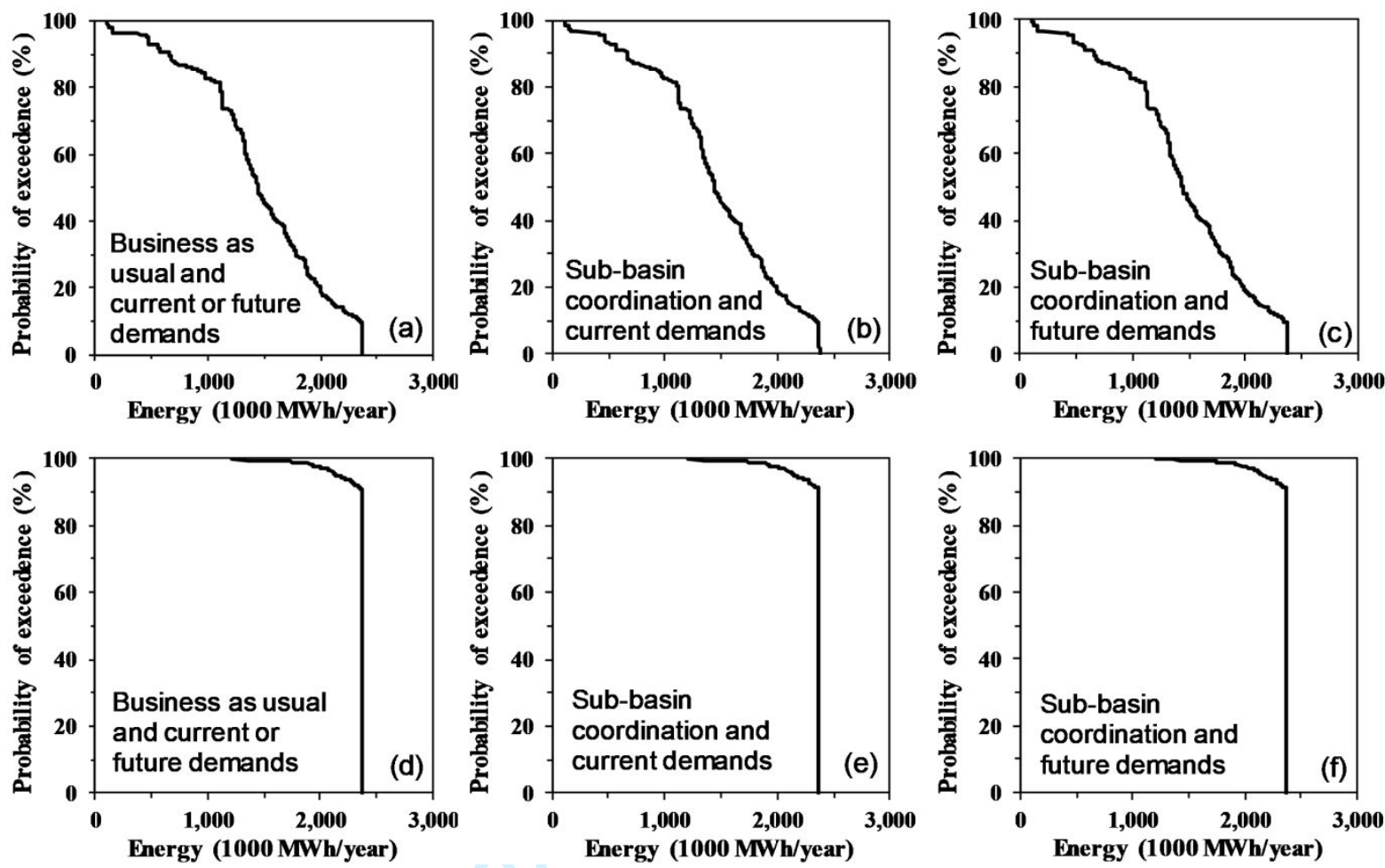

Figure 7. Probability of exceedance of Tekeze-5 Dam annual energy generation with Tekeze-5

Dam starting at $1120 \mathrm{~m}$ asl: (a), (b), and (c) below-normal hydrologic conditions and (d), (e), and (f) above-normal hydrologic conditions. 


\section{List of figure captions and notes}

Figure 1. Topography, dams, irrigation schemes, and rainfall and discharge stations in the study area.

Note: UASDC = Upper Atbara and Setit Dam Complex; GIS=Geographic Information System; ENTRO = Eastern Nile Technical Regional Office; SRTM=Shuttle Radar Topography Mission; DEM=Digital Elevation Model; FSL = Full Supply Level.

Figure 2. Tekeze-Atbara flow volume over the period 1984 to 2016: (a) average monthly (b) annual Standardized Streamflow Index (SSFI; Modarres (2007)).

Figure 3. Schematic of the model developed for the study area.

Note: UASDC = Upper Atbara and Setit Dam Complex; KED = Khashm Elgirba Dam

Figure 4. Reservoir surface area of Tekeze-5. The sub-figure in the bottom right corner shows and a time series of the reservoir water level from the commencement of the filling until the end of 2016. The displayed data are based on Landsat satellite images.

Note: $\mathrm{MOL}=$ Minimum Operating Level; FSL = Full Supply Level

Figure 5. Daily observed and simulated outflow from Khashm Elgirba Dam: (a) time series of the calibration and validation periods (b) scatterplot of the calibration period (c) scatterplot of the validation period. In figures $b$ and $c$, the continuous and dashed lines represent the 1:1 and regression lines, respectively.

Figure 6. Sudan's annual water supply shortages and energy generation with different dam operation scenarios and Tekeze-5 Dam starting at $1120 \mathrm{~m}$ asl: (a), (b), (c), and (d) probability of exceedance of water supply shortages and (e), (f), (g), and (h) probability of exceedance of energy generation.

Figure 7. Probability of exceedance of Tekeze-5 Dam annual energy generation with Tekeze-5 Dam starting at 1120 m asl: (a), (b), and (c) below-normal hydrologic conditions and (d), (e), and (f) above-normal hydrologic conditions. 
Exploring management approaches for water and energy in the data-scarce Tekeze-Atbara Basin under hydrologic uncertainty

\title{
Supplementary data
}

\author{
Mohammed Basheer a, b, *, Rayyan Sulieman a, Lars Ribbe a \\ ${ }^{a}$ Institute for Technology and Resources Management in the Tropics and Sub-tropics (ITT), Technische \\ Hochschule Köln, Betzdorferstr. 2, 50679, Cologne, Germany \\ ${ }^{b}$ Current affiliation: School of Mechanical, Aerospace, and Civil Engineering, The University of \\ Manchester, Manchester, United Kingdom
}

*Corresponding author’s email: mohammedadamabbaker@gmail.com 
Exploring management approaches for water and energy in the data-scarce Tekeze-Atbara Basin under hydrologic uncertainty

\section{Performance of satellite-based rainfall products}

In the present study, the performance of five daily long-term SRPs (i.e., ARC2, CHIRPS v2.0, MSWEP 2.0, PERSIANN-CDR, and TAMSAT-2) was evaluated using daily rainfall data (1984 to 2007) from ground stations that are in or near the study area (Figure 1 in the main body of the paper shows the locations of the stations). Even though several studies assessed the performance of SRPs in Africa and the Nile Basin (Basheer et al., 2018; Basheer \& Elagib, 2018b, 2018a; Diem, Hartter, Ryan, \& Palace, 2014; T Dinku et al., 2007; Gebremicael, Mohamed, Zaag, \& Hagos, 2017; Habib, Elsaadani, \& Haile, 2012; Serrat-Capdevila, Merino, Valdes, \& Durcik, 2016), none compared the performance of long-term SRPs in Tekeze-Atbara Basin. Figure S1 presents the results of the six metrics (i.e., RMSE, MBE, $\mathrm{R}^{2}$, POD, FAR, and ETS) that were used to assess the performance of the SRPs. PERSIANN-CDR showed the best performance at all stations in terms of RMSE which varies from $0.04 \mathrm{~mm}$ at Dongola to $8.96 \mathrm{~mm}$ at Bahir Dar. The second-best performance was achieved by MSWEP 2.0 at Dongola, Kassla, New Halfa, and Gedarif, CHERPS v2.0 at Atbara and Bahir Dar, and ARC2 at Gondar. Moreover, the worst performance based on RMSE is a feature of TAMSAT-2 at Bahir Dar and Atbara and CHIRPS v2.0 at Gondar, Gedarif, New Halfa, Kassla, and Dongola. Generally, RMSE values suggest worse performance towards the upstream. This characteristic is because the five SRPs use InfraRed (IR) imagery as a primary input. Rainfall estimation based on IR imagery is known to poorly capture local heavy precipitation events that result from warm clouds (Maidment et al., 2017; Novella \& Thiaw, 2013). Such events occur in the mountainous upstream part TekezeAtbara Basin (Tufa Dinku, Ceccato, \& Connor, 2011). MBE showed mixed performances among the products with ARC2 outperforming at Dongola, Kassla, and Gondar, CHIRPS v2.0 at Atbara, 


\section{Exploring management approaches for water and energy in the data-scarce Tekeze-Atbara Basin under hydrologic uncertainty}

New Halfa, and Gedarif, and TAMSAT-2 at Bahir Dar. Regarding R², ARC2 showed the best performance at all stations except Bahir Dar where PERSIANN-CDR performed the best. TAMSAT-2 showed the lowest $\mathrm{R}^{2}$ values at all stations. It is worth noting that all Pearson correlation coefficient $(\mathrm{R})$ values of ARC2 are statistically significant at $\mathrm{p}<0.0001$.

With regards to the categorical metrics, PERSIANN-CDR showed the best detection capability of rainy days explained by the highest POD values at all stations except Gondar at which ARC2 showed the best performance. The latter product exhibited the second-best performance at the other six stations, and TAMSAT-2 revealed the worst performance at all stations. Regarding FAR and ETS, ARC2 presented the best performance at all stations explained by the lowest FAR and the highest ETS values. In contrast, TAMSAT-2 showed the worst performance at all stations based on FAR and ETS. It can be noticed that the high POD values of PERSIANN-CDR were coupled with relatively high FAR values. This behaviour could be due to the likelihood of having more false alarms with the increase in detection skill.

Overall, ARC2 showed either the best or the second-best performance at most of the stations and with most of the performance metrics. Moreover, ARC2 showed better performance in the flat terrain of Sudan than in the Ethiopian highlands using all performance metrics except POD. 
Exploring management approaches for water and energy in the data-scarce Tekeze-Atbara Basin under hydrologic uncertainty
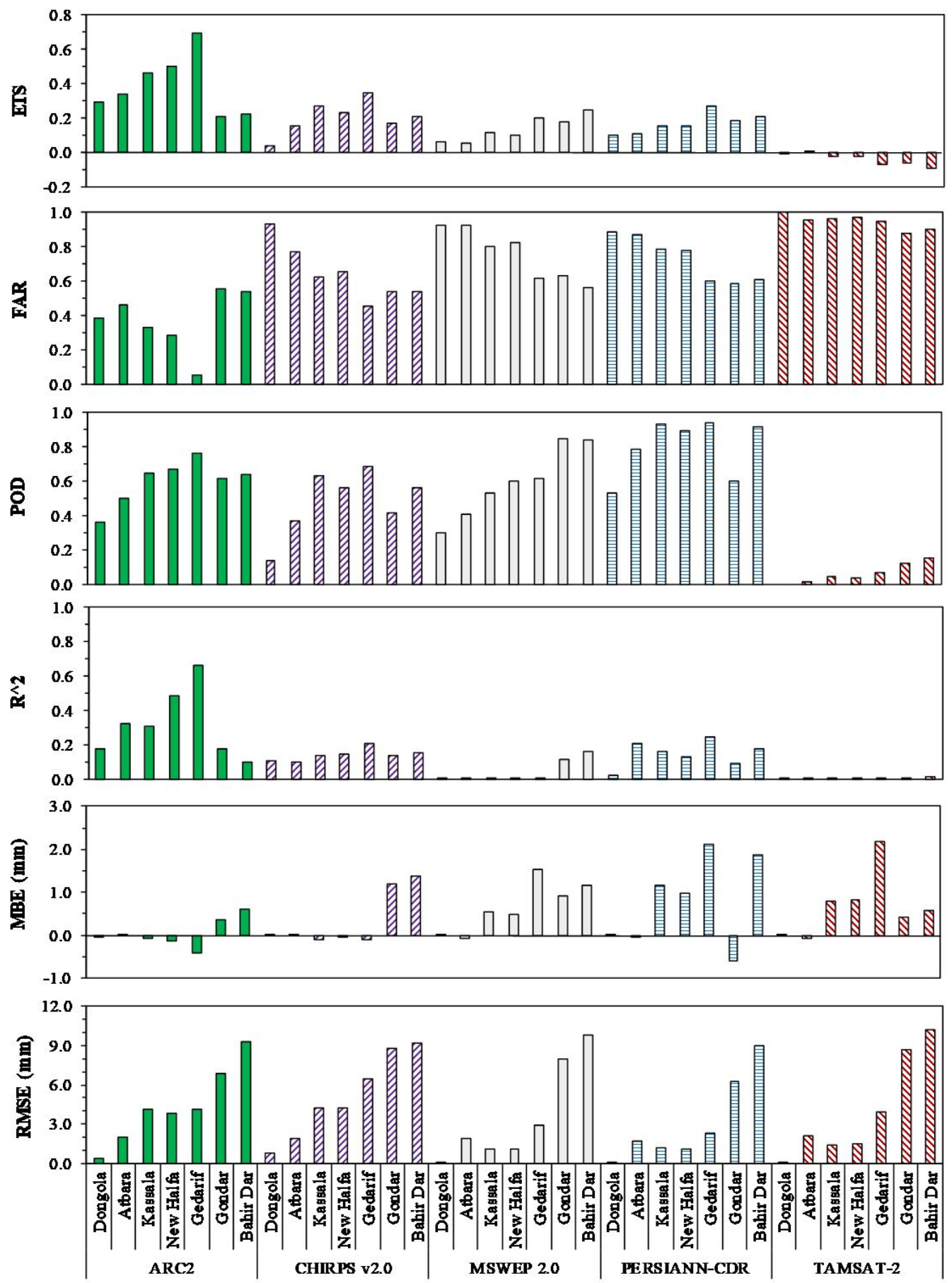

Figure S1. Performance metrics of the evaluated Satellite-based Rainfall Products at seven rainfall stations.

Note: $R M S E=$ Root Mean Square Error; $M B E=$ Mean Bias Error; $R^{\wedge} 2=$ Coefficient of determination; $P O D=$ Probability Of Detection; FAR = False Alarm Ration; ETS = Equitable Threat Score; ARC2 = Africa Rainfall Climatology Version 2.0; CHIRPS v2.0 = Climate Hazards group Infrared Precipitation with Stations version 2.0; MSWEP 2.0 = Multi-Source Weighted-Ensemble Precipitation version 2.0; PERSIANN-CDR $=$ Precipitation Estimation from Remotely Sensed Information Using Artificial Neural Networks-Climate Data Record; TAMSAT-2 = Tropical Applications of Meteorology Using Satellite Data and Ground-Based Observations version 2.0 
Exploring management approaches for water and energy in the data-scarce Tekeze-Atbara Basin under hydrologic uncertainty

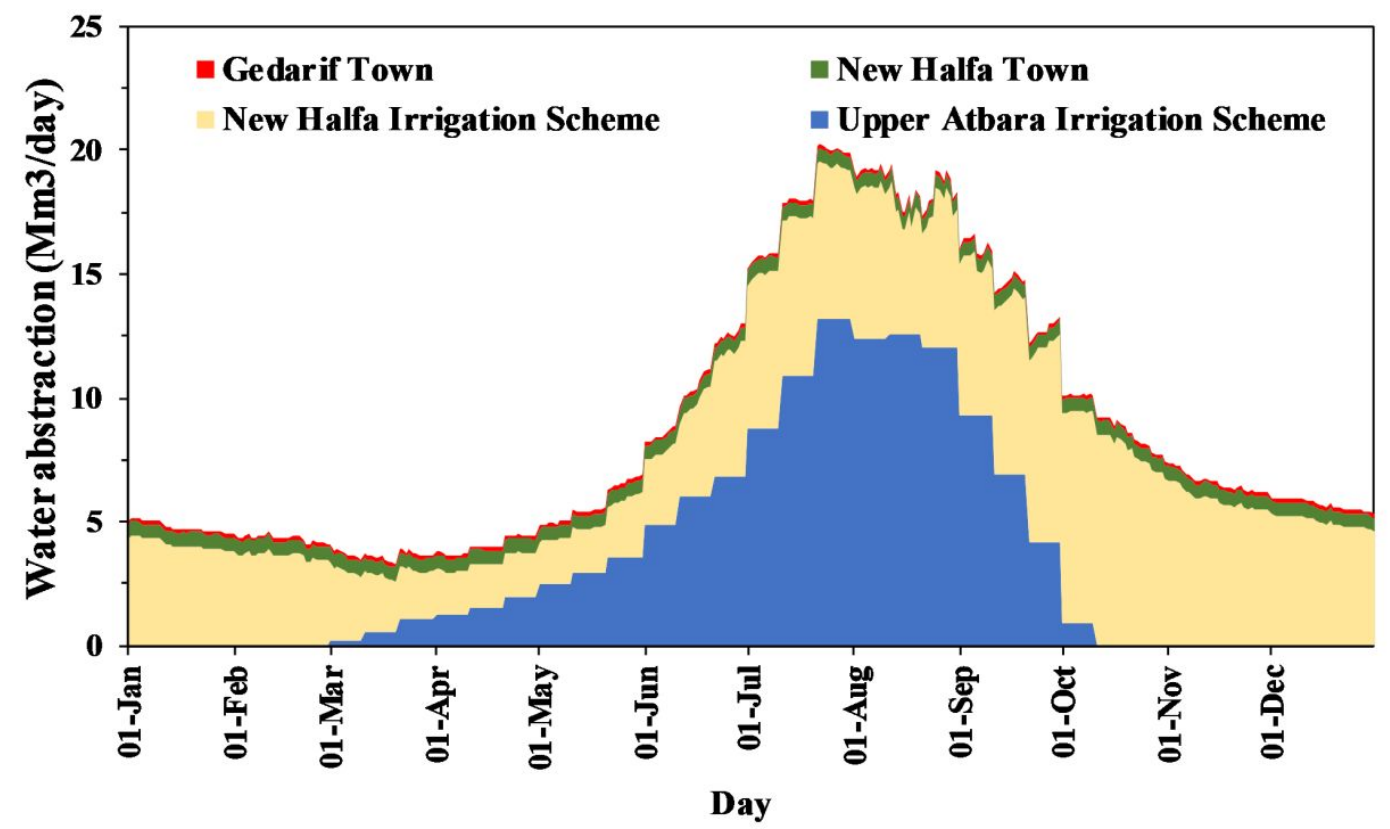

Figure S2 Water abstraction in the study area

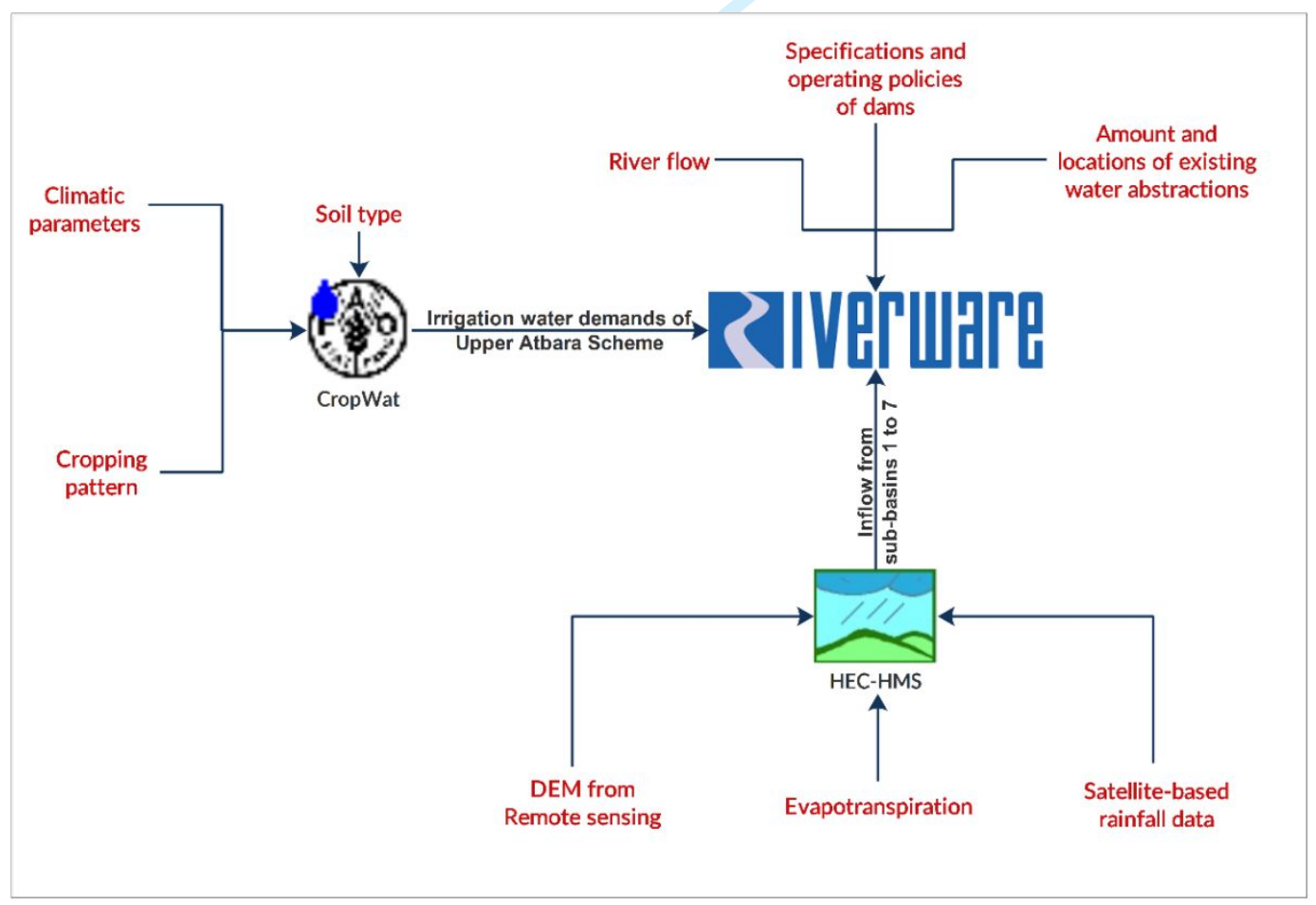

Figure S3 Modeling tools utilised in this study 
Exploring management approaches for water and energy in the data-scarce Tekeze-Atbara Basin under hydrologic uncertainty

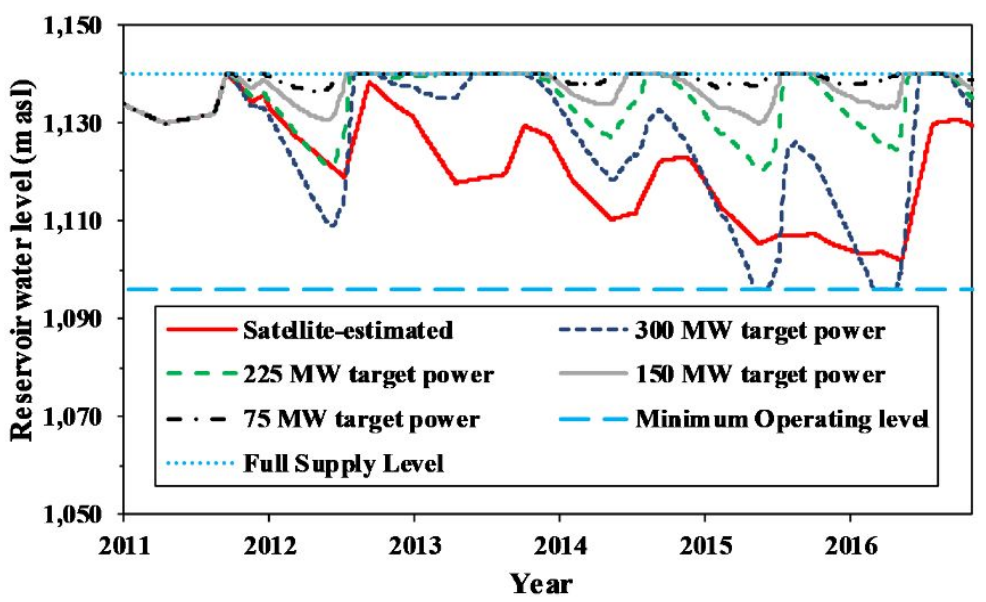

Figure S4 Satellite-estimated and modelled Tekeze-5 reservoir water levels with different power targets

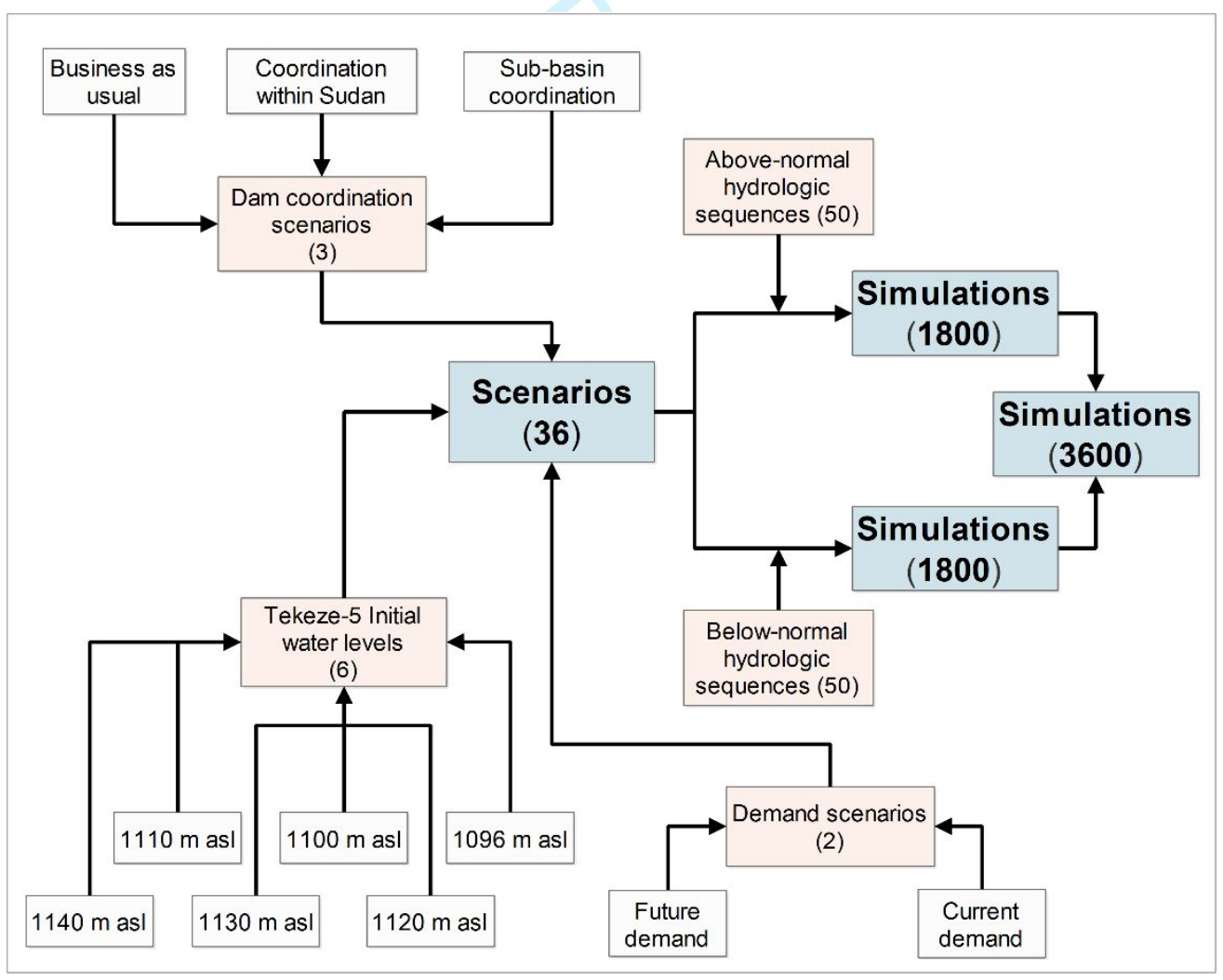

Figure S5 Scenarios developed for the study area 


\section{Exploring management approaches for water and energy in the data-scarce Tekeze-Atbara Basin under hydrologic uncertainty}

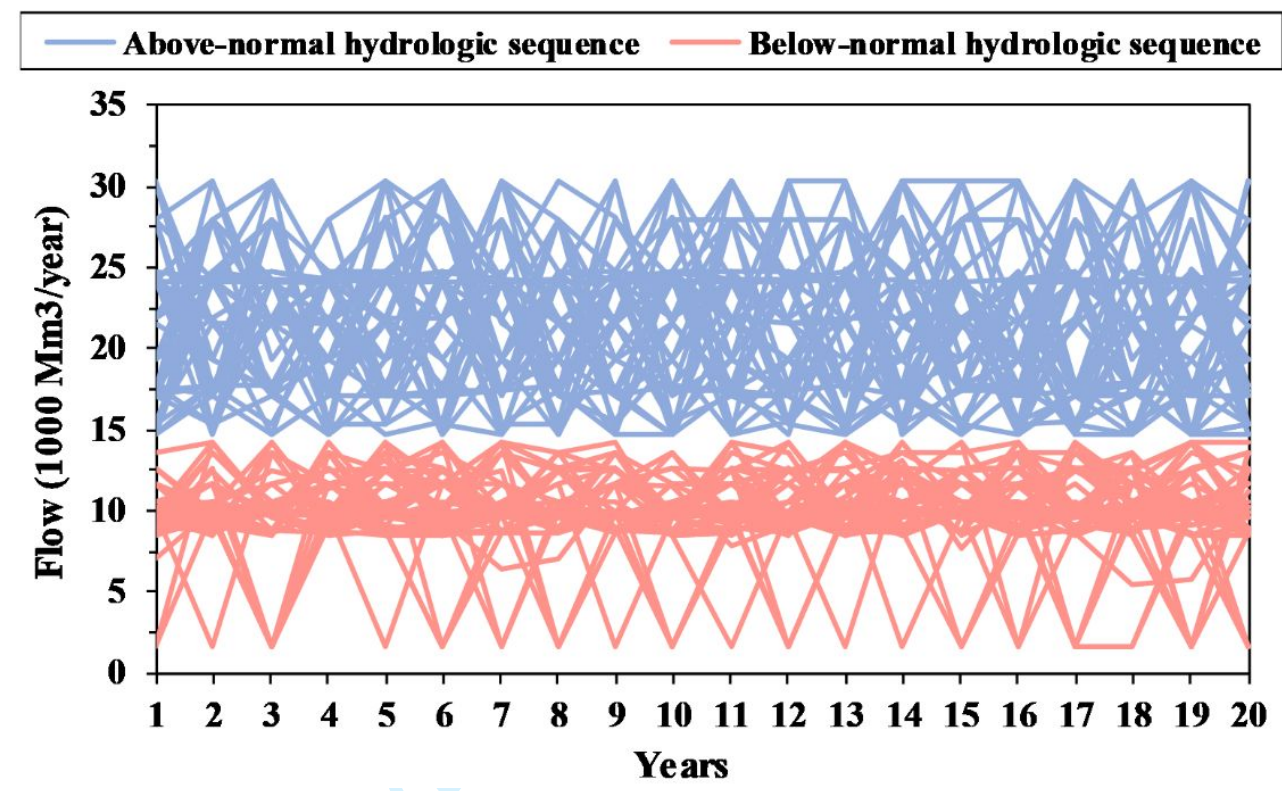

Figure S6 Hydrologic sequences generated for Tekeze-Atbara River

Table S1 Operating rules of dams located in the study area in the business as usual (i.e., current) scenario.

\begin{tabular}{|c|c|c|c|}
\hline Priority & Khashm Elgirba Dam a & Upper Atbara and Setit Dam Complex a & Tekeze-5 Dam \\
\hline 1 & $\begin{array}{l}\text { The reservoir should be } \\
\text { flushed in two to three days } \\
\text { in mid-august }\end{array}$ & $\begin{array}{l}\text { The reservoir should be flushed in two to } \\
\text { three days in mid-august }\end{array}$ & $\begin{array}{l}\text { The reservoir water level } \\
\text { should remain higher than } \\
\text { the minimum operating level }\end{array}$ \\
\hline 2 & $\begin{array}{l}\text { The reservoir water level } \\
\text { should remain higher than } \\
\text { the minimum operating level }\end{array}$ & $\begin{array}{l}\text { The reservoir water level should remain } \\
\text { higher than the minimum operating level }\end{array}$ & $\begin{array}{l}\text { The reservoir water level } \\
\text { should remain lower than the } \\
\text { full supply level }\end{array}$ \\
\hline 3 & $\begin{array}{l}\text { The reservoir water level } \\
\text { should remain lower than the } \\
\text { full supply level }\end{array}$ & $\begin{array}{l}\text { The reservoir water level should remain } \\
\text { lower than the full supply level }\end{array}$ & Meet a power target ${ }^{b}$ \\
\hline 4 & $\begin{array}{l}\text { Target certain water levels } \\
\text { from June to mid-October }\end{array}$ & $\begin{array}{l}\text { Meet the demand of Gedarif Town when } \\
\text { the supply pipeline is constructed }\end{array}$ & \\
\hline 5 & $\begin{array}{l}\text { Meet the water demands of } \\
\text { New Halfa Scheme and } \\
\text { Town and Upper Atbara } \\
\text { Scheme when constructed }\end{array}$ & Meet a power target & \\
\hline 6 & & arget certain water levels & \\
\hline
\end{tabular}

a Source: Ministry of Water Resources, Irrigation, and Electricity of Sudan

${ }^{\mathrm{b}}$ Source: derived from Landsat 7 and 8 satellite images as explained in the paper 


\section{Exploring management approaches for water and energy in the data-scarce Tekeze-Atbara Basin under hydrologic uncertainty}

Table S2 Operating rules of dams located in the study area in the coordination within Sudan scenario.

\begin{tabular}{llll}
\hline Priority & Khashm Elgirba Dam & Upper Atbara and Setit Dam Complex & Tekeze-5 Dam \\
\hline $\mathbf{1}$ & $\begin{array}{l}\text { The reservoir should be } \\
\text { flushed in two to three days } \\
\text { in mid-august }\end{array}$ & $\begin{array}{l}\text { The reservoir should be flushed in two to } \\
\text { three days in mid-august }\end{array}$ & $\begin{array}{l}\text { The reservoir water level } \\
\text { should remain higher than } \\
\text { the minimum operating level }\end{array}$ \\
\hline $\mathbf{2}$ & $\begin{array}{l}\text { The reservoir water level } \\
\text { should remain higher than } \\
\text { the minimum operating level }\end{array}$ & $\begin{array}{l}\text { The reservoir water level should remain } \\
\text { higher than the minimum operating level }\end{array}$ & $\begin{array}{l}\text { The reservoir water level } \\
\text { should remain lower than the } \\
\text { full supply level }\end{array}$ \\
\hline $\mathbf{3}$ & $\begin{array}{l}\text { The reservoir water level } \\
\text { should remain lower than the } \\
\text { full supply level }\end{array}$ & $\begin{array}{l}\text { The reservoir water level should remain } \\
\text { lower than the full supply level }\end{array}$ & Meet a power target $^{\text {a }}$ \\
\hline $\mathbf{4}$ & $\begin{array}{l}\text { Target certain water levels } \\
\text { from June to mid-October }\end{array}$ & $\begin{array}{l}\text { Meet the deficit in the downstream water } \\
\text { supply and the demand of Gedarif Town } \\
\text { when the supply pipeline is constructed }\end{array}$ & \\
\hline $\mathbf{5}$ & $\begin{array}{l}\text { Meet the water demands of } \\
\text { New Halfa Scheme and } \\
\text { Town and Upper Atbara } \\
\text { Scheme when constructed }\end{array}$ & Meet a power target & \\
& & & \\
\hline $\mathbf{6}$ & Target certain water levels & \\
\hline
\end{tabular}

a Source: derived from Landsat 7 and 8 satellite images as explained in the paper

Table S3 Operating rules of dams located in the study area in the sub-basin coordination scenario.

\begin{tabular}{llll}
\hline Priority & Khashm Elgirba Dam & Upper Atbara and Setit Dam Complex & Tekeze-5 Dam \\
\hline $\mathbf{1}$ & $\begin{array}{l}\text { The reservoir should be } \\
\text { flushed in two to three days } \\
\text { in mid-august }\end{array}$ & $\begin{array}{l}\text { The reservoir should be flushed in two to } \\
\text { three days in mid-august }\end{array}$ & $\begin{array}{l}\text { The reservoir water level } \\
\text { should remain higher than } \\
\text { the minimum operating level }\end{array}$ \\
\hline $\mathbf{2}$ & $\begin{array}{l}\text { The reservoir water level } \\
\text { should remain higher than } \\
\text { the minimum operating level }\end{array}$ & $\begin{array}{l}\text { The reservoir water level should remain } \\
\text { higher than the minimum operating level }\end{array}$ & $\begin{array}{l}\text { The reservoir water level } \\
\text { should remain lower than the } \\
\text { full supply level }\end{array}$ \\
\hline $\mathbf{3}$ & $\begin{array}{l}\text { The reservoir water level } \\
\text { should remain lower than the } \\
\text { full supply level }\end{array}$ & $\begin{array}{l}\text { The reservoir water level should remain } \\
\text { lower than the full supply level }\end{array}$ & $\begin{array}{l}\text { Meet the deficit in the } \\
\text { downstream water supply }\end{array}$ \\
\hline $\mathbf{4}$ & $\begin{array}{l}\text { Target certain water levels } \\
\text { from June to mid-October }\end{array}$ & $\begin{array}{l}\text { Meet the deficit in the downstream water } \\
\text { supply and the demand of Gedarif Town } \\
\text { when the supply pipeline is constructed }\end{array}$ & Meet a power target a $^{\text {a }}$ \\
\hline $\mathbf{5}$ & $\begin{array}{l}\text { Meet the water demands of } \\
\text { New Halfa Scheme and } \\
\text { Town and Upper Atbara } \\
\text { Scheme when constructed }\end{array}$ & Meet a power target & \\
\hline $\mathbf{6}$ & & & Target certain water levels \\
\end{tabular}

${ }^{\text {a }}$ Source: derived from Landsat 7 and 8 satellite images as explained in the paper 
Exploring management approaches for water and energy in the data-scarce Tekeze-Atbara Basin under hydrologic uncertainty

Table S4 Geometry of the reservoirs located in the study area.

\begin{tabular}{|c|c|c|c|c|c|c|c|c|}
\hline \multicolumn{3}{|c|}{ Tekeze-5 in 2016} & \multicolumn{3}{|c|}{ Khashm Elgirba in 1990} & \multicolumn{3}{|c|}{ UASDC in 2015} \\
\hline $\begin{array}{c}\text { Elevation } \\
\text { (masl) }\end{array}$ & $\begin{array}{l}\text { Storage } \\
\text { (Mm3) }\end{array}$ & $\begin{array}{c}\text { Surface } \\
\text { area } \\
\left(\mathbf{k m}^{2}\right)\end{array}$ & $\begin{array}{c}\text { Elevation } \\
\text { (masl) }\end{array}$ & $\begin{array}{c}\text { Storage } \\
\text { (Mm3) }\end{array}$ & $\begin{array}{c}\text { Surface } \\
\text { area } \\
\left(\mathbf{k m}^{2}\right)\end{array}$ & $\begin{array}{c}\text { Elevation } \\
\text { (masl) }\end{array}$ & $\begin{array}{l}\text { Storage } \\
\text { (Mm3) }\end{array}$ & $\begin{array}{c}\text { Surface } \\
\text { area } \\
\left(\mathbf{k m}^{2}\right)\end{array}$ \\
\hline 1,000 & 69 & 5 & 464 & 27 & 11 & 495 & 157 & 24 \\
\hline 1,010 & 134 & 8 & 465 & 43 & 19 & 500 & 365 & 52 \\
\hline 1,020 & 245 & 14 & 466 & 55 & 25 & 505 & 730 & 89 \\
\hline 1,030 & 423 & 22 & 467 & 67 & 32 & 508 & 1,048 & 116 \\
\hline 1,040 & 678 & 30 & 468 & 95 & 41 & 510 & 1,311 & 139 \\
\hline 1,050 & 1,023 & 40 & 469 & 131 & 52 & 515 & 2,165 & 206 \\
\hline 1,060 & 1,474 & 51 & 470 & 176 & 63 & 520 & 3,358 & 278 \\
\hline 1,070 & 2,036 & 62 & 471 & 238 & 72 & 525 & 5,007 & 398 \\
\hline 1,080 & 2,707 & 73 & 472 & 315 & 81 & 530 & 7,280 & 511 \\
\hline 1,090 & 3,480 & 82 & 473 & 403 & 90 & \multicolumn{3}{|c|}{ Source: MoWRIE } \\
\hline 1,100 & 4,354 & 93 & 474 & 628 & 100 & & & \\
\hline 1,130 & 7,810 & 140 & \multicolumn{3}{|c|}{ Source: MoWRIE } & & & \\
\hline 1,140 & 9,293 & 157 & & & & & & \\
\hline 1,150 & 10,958 & 176 & & & & & & \\
\hline \multicolumn{3}{|c|}{ Source: ENTRO } & & & & & & \\
\hline
\end{tabular}

Note: ENTRO = Eastern Nile Technical Regional Office; MoWRIE = Ministry of Water Resources, Irrigation, and Electricity of Sudan 
Exploring management approaches for water and energy in the data-scarce Tekeze-Atbara Basin under hydrologic uncertainty

Table S5 Net evaporation coefficients of the reservoirs located in the study area.

\begin{tabular}{|c|c|c|c|}
\hline Month & $\begin{array}{c}\text { Tekeze-5 in 2016 } \\
(\mathbf{c m})\end{array}$ & $\begin{array}{c}\text { Khashm Elgirba } \\
\text { in 1990 (cm) }\end{array}$ & $\begin{array}{c}\text { UASDC in } \\
\mathbf{1 9 8 5}(\mathbf{c m})\end{array}$ \\
\hline January & 13.4 & 17.9 & 16.7 \\
\hline February & 14.4 & 18.4 & 16.4 \\
\hline March & 9.9 & 20.9 & 21.3 \\
\hline April & 8.0 & 25.6 & 23.8 \\
\hline May & 7.9 & 26.3 & 23.7 \\
\hline June & 0.2 & 27.8 & 20.3 \\
\hline July & -15.4 & 24.9 & 17.7 \\
\hline August & -18.3 & 22.7 & 16.3 \\
\hline September & -3.8 & 21.1 & 17.1 \\
\hline October & 11.3 & 20.5 & 18.1 \\
\hline November & 14.7 & 18.3 & 17.6 \\
\hline December & 14.7 & 16.8 & 16.6 \\
\hline \multirow{2}{*}{} & Source: & Source: MoWRIE & Source: \\
& Wheeler et al. (2016) & & MoWRIE \\
\cline { 2 - 4 } & & &
\end{tabular}

Note: ENTRO = Eastern Nile Technical Regional Office; MoWRIE = Ministry of Water Resources, Irrigation, and Electricity of Sudan

\section{References}

Basheer, M., \& Elagib, N. A. (2018a). Performance of satellite-based and GPCC 7.0 rainfall products in an extremely data-scarce country in the Nile Basin. Atmospheric Research, 215(1 January 2019), 128-140. https://doi.org/10.1016/j.atmosres.2018.08.028

Basheer, M., \& Elagib, N. A. (2018b). Sensitivity of Water-Energy Nexus to dam operation: A Water-Energy Productivity concept. Science of The Total Environment, 616-617(March 2018), 918-926. https://doi.org/10.1016/j.scitotenv.2017.10.228

Basheer, M., Wheeler, K. G., Ribbe, L., Majdalawi, M., Abdo, G., \& Zagona, E. A. (2018). Quantifying and evaluating the impacts of cooperation in transboundary river basins on the Water-Energy-Food nexus: The Blue Nile Basin. Science of the Total Environment, 630, 1309-1323. https://doi.org/10.1016/j.scitotenv.2018.02.249

Diem, J., Hartter, J., Ryan, S., \& Palace, M. (2014). Validation of Satellite Rainfall Products for Western Uganda. Journal of Hydrometeorology, 15, 2030-2038. 
Exploring management approaches for water and energy in the data-scarce Tekeze-Atbara Basin under hydrologic uncertainty

https://doi.org/10.1175/JHM-D-13-0193.1

Dinku, T., Ceccato, P., \& Connor, S. J. (2011). Challenges of satellite rainfall estimation over mountainous and arid parts of east africa. International Journal of Remote Sensing, 32(21), 5965-5979. https://doi.org/10.1080/01431161.2010.499381

Dinku, T., Ceccato, P., Grover-Kopec, E., Lemma, M., Connor, S., \& Ropelewski, C. (2007). Validation of satellite rainfall products over East Africa's complex topography. International Journal of Remote Sensing, 28(7), 1503-1526. https://doi.org/10.1080/01431160600954688

Gebremicael, T. G., Mohamed, Y. A., Zaag, P. V., \& Hagos, E. Y. (2017). Temporal and spatial changes of rainfall and streamflow in the Upper Tekezē-Atbara river basin, Ethiopia. Hydrology and Earth System Sciences, 21(4), 2127-2142. https://doi.org/10.5194/hess-212127-2017

Habib, E., Elsaadani, M., \& Haile, A. (2012). Climatology-Focused evaluation of CMORPH and TMPA satellite rainfall products over the Nile Basin. Journal of Applied Meteorology and Climatology, 51(12), 2105-2121. https://doi.org/10.1175/JAMC-D-11-0252.1

Maidment, R. I., Grimes, D., Black, E., Tarnavsky, E., Young, M., Greatrex, H., ... Alcántara, U. (2017). A new , long-term daily satellite-based rainfall dataset for operational monitoring in Africa. Scientific Data, 4, 1-19. https://doi.org/10.1038/sdata.2017.63

Novella, N., \& Thiaw, W. (2013). African rainfall climatology version 2 for famine early warning systems. Journal of Applied Meteorology and Climatology, 52, 588-606. https://doi.org/10.1175/JAMC-D-11-0238.1

Serrat-Capdevila, A., Merino, M., Valdes, J., \& Durcik, M. (2016). Evaluation of the Performance of Three Satellite Precipitation Products over Africa. Remote Sensing, 8(10), 836. https://doi.org/10.3390/rs8100836

Wheeler, K., Basheer, M., Mekonnen, Z., Eltoum, S., Mersha, A., Abdo, G., ... Dadson, S. (2016). Cooperative filling approaches for the Grand Ethiopian Renaissance Dam. Water International, 8060(May), 1-24. https://doi.org/10.1080/02508060.2016.1177698 